\title{
Comparison of N. Atlantic heat storage estimates during the Argo period (1999-2010)
}

Comparison of $\mathbf{N}$. Atlantic heat storage

N. C. Wells et al.

\section{N. C. Wells ${ }^{1}$, M. Couldrey ${ }^{1}$, and V. O. Ivchenko ${ }^{2}$}

${ }^{1}$ University of Southampton, National Oceanography Centre, Southampton, UK

${ }^{2}$ Alfred-Wegener Institute, Bremerhaven, Germany

Received: 16 September 2013 - Accepted: 1 November 2013 - Published: 6 December 2013 Correspondence to: N. C. Wells (ncw@noc.soton.ac.uk) and M. Couldrey (couldrey.matthew@gmail.com)

Published by Copernicus Publications on behalf of the European Geosciences Union.

\section{Title Page}

Abstract Introduction

Conclusions References

Tables Figures

14

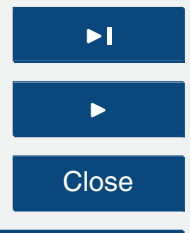

Full Screen / Esc

Printer-friendly Version

Interactive Discussion 


\section{Abstract}

Ocean heat storage is an essential component of the climate system and there is considerable interest in its accurate evaluation. There are a number of heat storage products produced by many different groups. These products are derived from Argo 5 as well as other platforms, for example XBT and CTD, in the last decade. Here we compare two heat storage estimates for the North Atlantic $0-2000 \mathrm{~m}$ from $10^{\circ}$ to $70^{\circ} \mathrm{N}$. One derived solely from Argo data whilst the other is derived from Argo and other platforms. It is found that there is a positive trend in heat storage over the period 19992010. This trend is influenced by a strong air-sea interaction event in 2009-2010, and this reduces the upward trend 1999-2008 identified previously. Both data sets are consistent with each other for the layer $0-1000 \mathrm{~m}$ on a timescale of beyond $1 \mathrm{yr}$. There are significant differences at sub-annual time scales and in the layer 1000-2000 m.

\section{Introduction}

The heat content of the global ocean has received close attention over the last two 15 decades for its detection of the anthropogenic radiative warming that the global ocean has been receiving since the 19th Century (Levitus et al., 2005, 2009). The heat and salt content in the North Atlantic Ocean has been investigated using pre-Argo data sets (Dickson et al., 1996, 2002; Lozier et al., 2008). These data sets have shown decadal variability in the North Atlantic Ocean in both temperature and salinity from 1950.

After 1998 the Argo profiling floats have provided consistent and accurate set of observations over the global upper ocean. The Argo programme has relied on floats extending to a maximum depth of $2000 \mathrm{~m}$. The autonomous floats have been placed in the ocean by an international community of scientists. They are free floating and the profiles they have taken are of variable depth and frequency set by individual sciena spacing of $150 \mathrm{~km} \times 150 \mathrm{~km}$ as a standard as well as advising on placing floats in
OSD

10, 2363-2398, 2013

Comparison of $\mathbf{N}$. Atlantic heat storage

N. C. Wells et al.

\section{Title Page}

Abstract Introduction

Conclusions

References

Tables

Figures

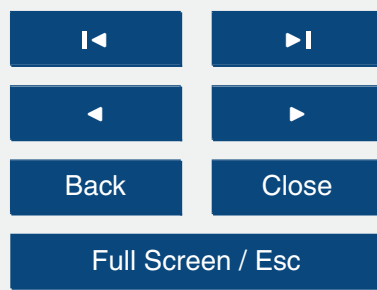

Printer-friendly Version

Interactive Discussion 
poorly sampled regions. The data set is therefore heterogeneous in time and space which makes measurement of heat content over a large spatial domain difficult. In particular the floats will only be retained in strong western boundary currents such as the Gulf Stream for a short period of time of a few weeks and therefore these regions are 5 sparsely sampled. Secondly floats have a mean life time of $3.7 \mathrm{yr}$ and are replaced continuously to maintain an array of over 3000 floats. The floats are generally restricted to a depth of $1000 \mathrm{~m}$ or deeper and therefore exclude the ocean margin. Finally the floats have a nominal resolution of $150 \mathrm{~km} \times 150 \mathrm{~km}$ and therefore they cannot resolve mesoscale eddies without additional information from other measurements for example 10 the satellite altimeter and XBT profiles.

This paper compares two heat content data sets in the upper N. Atlantic Ocean (0$2000 \mathrm{~m}$ ) from 1999 to 2010 . The first data set is known as TAMARA. In particular the $12 \mathrm{yr}$ trends in heat content in the upper North Atlantic since 1999 are compared with previous estimates from Ivchenko et al. $(2010,2006)$. These estimates of heat content 15 are also compared with a data set from the UKMetOffice, over this $12 \mathrm{yr}$ period and over a similar depth, and is known as EN3.

The question which will be addressed are how good are these estimates of heat storage and in particular what are the spatial and temporal scales that can be adequately resolved?

20 Finally on what time and spatial scales is there agreement between the two data sets (TAMARA and EN3)?

Ivchenko et al. (2010) used objectively-analysed Argo profiling float data to quantify trends in the heat content of the North Atlantic from January 1999 to December 2008. Spatially, the area of study was constrained to the upper $2000 \mathrm{~m}$ between 10 and $2570^{\circ} \mathrm{N}$ and 90 to $0^{\circ} \mathrm{E}$. The TAMARA data set has been extended to December 2010 using the same methodology as that described by Ivchenko et al. (2010). The Argo dataset is unique with regard to its coverage, and as such it is difficult to validate. However, the UKMetOffice EN3 data set, is a quality-controlled dataset of objectively analysed ocean temperature and salinity profiles (Ingleby and Huddleston, 2007, and
OSD

10, 2363-2398, 2013

Comparison of $\mathbf{N}$. Atlantic heat storage

N. C. Wells et al.

\section{Title Page}

Abstract Introduction

Conclusions

References

Tables

Figures

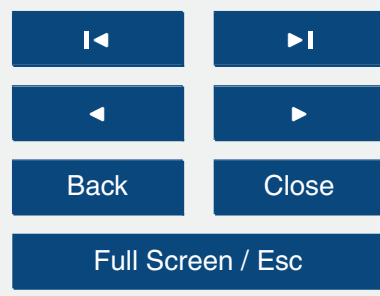

Printer-friendly Version

Interactive Discussion 
http://www.metoffice.gov.uk/hadobs/en3/). This dataset employs a wide range of data, most importantly for the purposes of this paper, Argo, but also the World Ocean Atlas 2005 (WOA05), Global Temperature-Salinity Profile Programme (GTSPP) and Arctic Synoptic Basin-wide Observation (ASBO) at NOCS. Therefore, this dataset employs 5 measurements from other platforms than Argo. This work uses this EN3 dataset to calculate trends of heat content anomaly (HCA), to provide a comparison for the values found by Ivchenko et al. (2010). The methods used here were intended to closely emulate those of Ivchenko et al. (2010) to provide the most robust comparison as well as extend the comparison from 2008 to December 2010. This study therefore provides 10 information on the reliability of these estimates of heat content which are needed to constrain the heat budget of the N. Atlantic Ocean.

The data sets are described in Sect. 2 and the results of the comparison in Sect. 3, followed by a discussion and conclusions in Sect. 4 .

\section{Methods and data sets}

15 The TAMARA Heat Content Anomalies were calculated for the $10^{\circ} \times 10^{\circ}$ boxes for four depth layers $(0-100 \mathrm{~m}, 100-500 \mathrm{~m}, 500-1000 \mathrm{~m}$ and $1000-2000 \mathrm{~m})$ as in Ivchenko et al. (2010) for each month. The EN3 data set is composed of actual monthly heat contents and not anomalies, and therefore to obtain the corresponding anomalies for EN3 we subtracted the same monthly climatology as used in TAMARA (WOA01, Stephens 20 et al., 2002) from the actual monthly values. The same depth levels were chosen for EN3 as TAMARA.

The construction of the TAMARA Heat Content Anomaly data set is based solely on Argo from 0 to $2000 \mathrm{~m}$ depth. For the analysis we select the period between January 1999 and December 2010 for the area between $10^{\circ} \mathrm{N}$ and $70^{\circ} \mathrm{N}$ at a horizontal

\section{OSD}

10, 2363-2398, 2013

Comparison of $\mathbf{N}$. Atlantic heat storage

N. C. Wells et al.

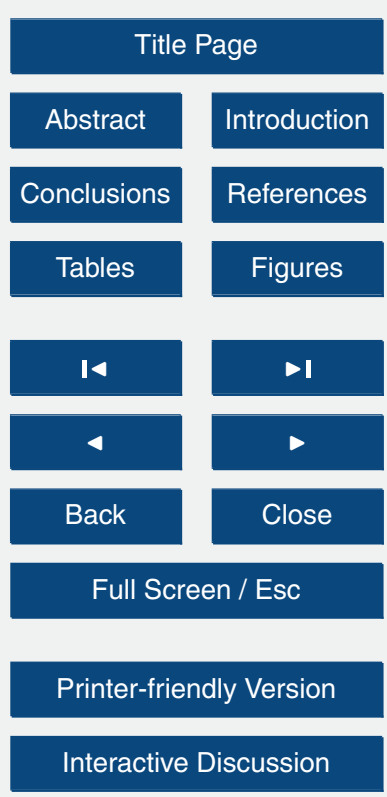
spatial coverage of the Argo floats in the early part of Argo period from 1999-2001 when there were fewer than 400 accepted profiles per month over the region $10-70^{\circ} \mathrm{N}$. 
This has subsequently increased from 2008 to more than 800 accepted profiles per month.

The number of the accepted data strongly depends on the depth. The number of temperature profiles per month at the surface increased from 200-300 in 1999 toward 5400 in 2001 . The number of profiles reduces with depth by $10-15 \%$ at $500 \mathrm{~m}$, and by $25-30 \%$ at $1500 \mathrm{~m}$.

To accept the Argo profiles we used our own quality control scheme on the delayed mode profiles from the Coriolis data centre in France. This is discussed in detail by Ivchenko et al. $(2006,2010)$. To calculate the heat content anomaly, we use a monthly 10 climatology WOA2001 (Stephens et al., 2002). This climatology is based on historical

hydrographic data from the end of the 1890's up to 2001. The majority of these data comes from the last half of the 20th century, and therefore is most representative of this latter period. This climatology is one of a number of ocean climatologies produced in the last decade and it has biases associated with it. In particular there is a bias 15 caused by XBT errors and this is discussed by Willis et al. (2009). Our reason for using this climatology is that it does not incorporate Argo data, and therefore it is an independent climatology. The estimates of HCA were obtained by the following method. The WOA2001 at a resolution of $1^{\circ}$ latitude by $1^{\circ}$ longitude was time interpolated to the time of the float observation between neighbouring months. It was then horizontally interpolated to the position of the float and the anomaly was obtained. The anomalies were objectively interpolated to the centre of each $10^{\circ}$ latitude by $10^{\circ}$ longitude box. The anomalies were then averaged over the $10^{\circ}$ latitude by $10^{\circ}$ longitude box for each month. The criterion for eliminating the float profiles from the data set was 4 standard deviations from the monthly climatology.

OSD

10, 2363-2398, 2013

Comparison of $\mathbf{N}$. Atlantic heat storage

N. C. Wells et al.

\section{Title Page}

Abstract Introduction

Conclusions

References

Tables

Figures

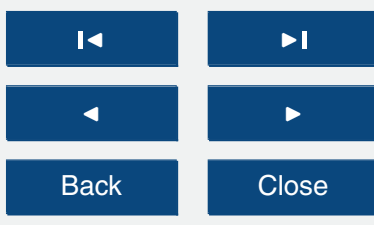

Full Screen / Esc

Printer-friendly Version

Interactive Discussion 


\section{Results}

\subsection{HCA in EN3 and TAMARA}

The comparison of the Heat Content Anomalies between EN3 and TAMARA showed that the EN3 anomalies here are higher than those of TAMARA in the upper layer $50-1000 \mathrm{~m}$ (Fig. 1). This offset is associated with the two different climatologies used. TAMARA used WOA 2001 whilst EN3 used WOA 2005. The EN3 data set consists of absolute values of monthly heat content whilst TAMARA has anomalies from the monthly climatology. For comparison purposes it was decided to calculate the EN3 anomalies with respect to WOA 2001 rather than WOA 2005. For these reasons we will focus here on the variations of these anomalies rather than on their absolute values.

The analysis of the results is done in the following way. The whole domain is considered first from $10-70^{\circ} \mathrm{N}$ for four depth layers: surface layer from 0-100 $\mathrm{m}$, upper thermocline from 100-500 m, lower thermocline from 500-1000 $\mathrm{m}$ and deep layer from $1000-2000 \mathrm{~m}$. These are combined into $0-1000 \mathrm{~m}$ and $0-2000 \mathrm{~m}$ heat content for the $1512 \mathrm{yr}$ period.

The TAMARA data set of Ivchenko et al. (2010) is extended by two extra years up to December 2010. The inclusion of another two years affects the trends of both datasets significantly, generally acting to reduce magnitudes of the trends. The trends for the two periods are shown in Tables 1 to 5 and Figs. 3 and 4.

20 From 2008 until the end of 2010, North Atlantic HCA decreased sufficiently to observably reduce the overall trend since 1999, shown in Figs. 1 and 2 . This shows the importance of the interannual variability of North Atlantic HCA, and the sensitivity of the trend to the length of the time series.

Upon the inclusion of the years 2009 and 2010, basin-wide trends in the upper three 25 layers of EN3 $(0-100 \mathrm{~m}, 100-500 \mathrm{~m}$ and $500-1000 \mathrm{~m})$ are no longer significant. The uncertainties become larger, relative to the trends themselves. In the TAMARA data, this is only seen for the $0-100 \mathrm{~m}$ layer, and the other trends remain significant at the

OSD

10, 2363-2398, 2013

Comparison of $\mathbf{N}$. Atlantic heat storage

N. C. Wells et al.

\section{Title Page}

Abstract Introduction

Conclusions

References

Tables

Figures

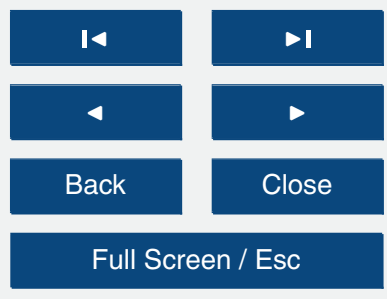

Printer-friendly Version

Interactive Discussion 
$95 \%$ level. A large positive trend in the 1000-2000 m layer is apparent for EN3 which is not seen in TAMARA and this will be discussed below.

For the TAMARA data sets (Table 1) there are significant (at $95 \%$ level) positive trends in all layers, except the surface layer. For EN3 only the 1000-2000 m and the 5 combined data set 0-2000 $\mathrm{m}$ show a positive significant trend. The variability in EN3 is much greater than in TAMARA therefore the trends in EN3 are not significant at this level. The trends in both data sets for all depth layers are always positive. This agrees with previous TAMARA analyses for the period 1999-2008 (Ivchenko et al., 2010).

However, the layer 1000-2000 m in EN3 shows a very large upward trend when compared with TAMARA. There are number of possibilities:

1. different analysis methods

2. different instruments used

3. the number and the spatial and temporality of the observations changed over the $12 \mathrm{yr}$ period.

15 Of these Argo floats about $85 \%$ obtained profiles down to $500 \mathrm{~m}$ depth and at least $70 \%$ obtained profiles down to $1500 \mathrm{~m}$ depth. Therefore the early part of the Argo period may not have been sufficient in time and space to obtain good heat storage estimates in the layer $1000-2000 \mathrm{~m}$ at the $10^{\circ} \times 10^{\circ}$ resolution. This will be analysed in Sect. 3.4.

20 For the 1999-2010 time series, zonal trends, for each $10^{\circ}$ latitude belt, were also calculated for both datasets up to December 2010, and shown in Table 2 and Fig. 5. The positive trends occur in the region $40-70^{\circ} \mathrm{N}$ in both data sets with the strongest $\mathrm{HCA}$ trend in the $50-60^{\circ} \mathrm{N}$ band. The TAMARA data shows consistently smaller trends than EN3 and smaller standard deviations than EN3.

25 Further south $20-40^{\circ} \mathrm{N}$ there are significant negative trends in EN3, whilst TAMARA shows a significant positive trend $20-30^{\circ} \mathrm{N}$. At the southernmost latitude belt $\left(10-20^{\circ} \mathrm{N}\right.$ band) neither trends are significant.

OSD

$10,2363-2398,2013$

Comparison of $\mathbf{N}$. Atlantic heat storage

N. C. Wells et al.

\section{Title Page}

Abstract Introduction

Conclusions

References

Tables

Figures

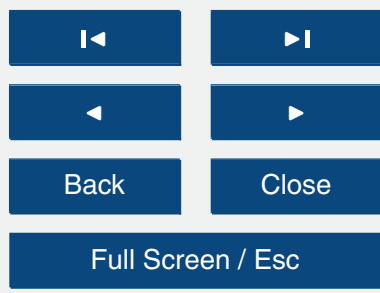

Printer-friendly Version

Interactive Discussion 
To further investigate the very strong trend in EN3 HCA between 1000-2000 m, the question arises whether this trend was evenly distributed across the North Atlantic, or confined to particular zonal bands. Table 3 and Fig. 6 illustrate the zonal trends in HCA for the layer between 1000-2000 m. The trends in EN3 for the northernmost three 5 zonal bands $40-70^{\circ} \mathrm{N}$ are very much larger than the same latitudes derived from the TAMARA dataset and they are all positive trends.

The region $10-30^{\circ} \mathrm{N}$ show smaller positive trends in both data sets than at higher latitudes $\left(>40^{\circ} \mathrm{N}\right)$ though they are both significant. The region $30-40^{\circ} \mathrm{N}$ has both negative trends but only TAMARA is significant.

\subsection{Comparison of trends 1999-2008 with trends 1999-2010}

The large air-sea interaction event in 2009 perturbed the N. Atlantic circulation in the sub-tropical latitudes (Taws et al., 2011). From the commencement of the RAPID project in 2004 it was the largest measured change in the MOC with a reduction of the circulation by $30 \%$ at $26^{\circ} \mathrm{N}$ during 2009 and a consequent reduction in northward 15 heat transport by a similar amount (McCarthy et al., 2012; Bryden et al., 2013). The influence of this 2009 event on the trends is analysed in Sect. 3.5.

The trend in heat content for the whole domain $\left(10-70^{\circ} \mathrm{N} \mathrm{0}-2000 \mathrm{~m}\right)$ showed a reduction in the positive trend from $10.44 \pm 3.16 \times 10^{21}$ for $1999-2008$ to $5.56 \pm 2.52 \times 10^{21} \mathrm{~J}$ for 1999-2010 in TAMARA and $20.22 \pm 6.93 \times 10^{21}$ to $11.60 \pm 5.25 \times 10^{21} \mathrm{~J}$ in EN3 for 20 similar periods. This is equivalent to a reduction in heat content of $53 \%$ and $57 \%$ respectively. Despite this large cooling event in 2009 the upward trend in heat content over the period 1999-2010 is above the 95\% significance level in both data sets.

Examination of the contributions of particular layers and latitude bands to the trends reveals differences between the two data sets. The TAMARA data set shows all lay-

ers, except the 0-100 m layer, still have significant positive trends for both time periods despite the cooling event in 2009. EN3 has significant upward trends for all the layers in the period 1999-2008 but only for the layer 1000-2000 $\mathrm{m}$ for the extended period 1999-2010. As we have discussed previously this layer has very different trends in the

OSD

10, 2363-2398, 2013

Comparison of $\mathbf{N}$. Atlantic heat storage

N. C. Wells et al.

\section{Title Page}

Abstract Introduction

Conclusions

References

Tables

Figures

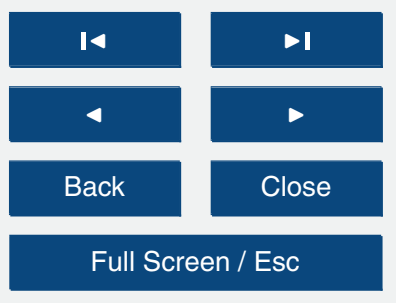

Printer-friendly Version

Interactive Discussion 
two data sets and therefore may be unreliable. The $0-1000 \mathrm{~m}$ layer has better correspondence between the two data sets and is shown in Tables 2 and 1. In TAMARA the latitude bands $20-30^{\circ} \mathrm{N}$ and $40-70^{\circ} \mathrm{N}$ have significant positive trends for both time periods, but in only EN3 are the latitude bands $20-40^{\circ} \mathrm{N}$ and $50-70^{\circ} \mathrm{N}$ regions significant. 5 To investigate the extended period further we consider a $3 \mathrm{yr}$ period (2008-2010) which contains the cooler year 2009 and this is discussed in Sect. 3.5.

\subsection{Time series analysis statistics: North Atlantic 10-70 , 1999-2010}

Descriptive statistics were also calculated for the pairs of HCA time series. Firstly, correlations were calculated between the TAMARA and EN3 HCAs, shown in Table 6 and 10 Fig. 7. Correlations were of consistently moderate values, with coefficient values between 0.43 and 0.55 . The comparative variability of the two time series was quantified through the standard deviations of the de-trended data, shown in Table 7 and Fig. 810. The standard deviations of the EN3 data were generally larger than those of the TAMARA time series, which was also reflected in the uncertainties of HCA trends.

\subsection{9-2010 North Atlantic HCA analysis}

To address the question about the lower number of Argo floats in the first six years and its influence on the overall heat content time series the data was split into two equal periods 1999-2004 and 2005-2010 respectively and from which the trends and correlations were calculated. In the first period TAMARA and EN3 had trends of $+1.26 \pm$ $205.1 \times 10^{21}$ and $+4.94 \pm 12.1 \times 10^{21} \mathrm{~J}$ respectively, whilst in the second period they had trends of $-0.88 \pm 4.1 \times 10^{21}$ and $-1.42 \pm 9.8 \times 10^{21} \mathrm{~J}$ respectively.

Given the uncertainty in the two time series it seems that there is no discernible difference in the two data sets. To further investigate this problem the trend in each period was removed and correlations were obtained. The correlation $(r)$ between TAMARA and EN3 in the first period was 0.37 and in the second period was 0.32 .
OSD

10, 2363-2398, 2013

Comparison of $\mathbf{N}$. Atlantic heat storage

N. C. Wells et al.

\section{Title Page}

Abstract Introduction

Conclusions

References

Tables

Figures

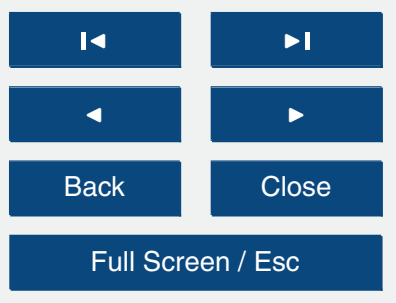

Printer-friendly Version

Interactive Discussion 
From this analysis there is no evidence for a significant difference between TAMARA and EN3 in the first period compared with the two data sets in the second period. However this does not rule out the possibility of a bias in both data sets.

Further analysis of the both time series (Table 8) show that when the two time series 5 were averaged over different time periods 3 months to 12 months the correlation $(r)$ increased from 0.44 to 0.89 . The EN3 again shows higher variance than TAMARA for all averaging periods. This was also investigated using filtering of the time series. When it was passed through a high pass filter with a cut-off period of 20 months the correlation was very low $(r=0.19)$ whilst with a low pass filter with a cut-off period of 20 months the correlation was high $(r=0.77)$.

\section{$3.52008-2010$ North Atlantic HCA}

The following analyses are just as described above, except they are only performed on the last three years of the HCA time series, when a large cooling event occurred. Note that zonal HCAs have been calculated using the full $2000 \mathrm{~m}$ depth range for this time 5 period, rather than the surface $1000 \mathrm{~m}$ as was done earlier.

EN3 and TAMARA were also compared over a 3 yr period between 2008-2010 when there was a large change in the heat content 0-2000 m (Figs. 11-13, Tables 9 and 10). All the trends in TAMARA are significant at the $95 \%$ significance levels, whilst only the zonal bands $30-40^{\circ} \mathrm{N}$ and $50-70^{\circ} \mathrm{N}$ are significant in EN3. Though the trends in both 20 data sets are relatively similar the variability in the EN3 data set is much larger than in TAMARA.

The significant negative trend in both data sets is evident in the $30-40^{\circ} \mathrm{N}$ band and the values are not different within $95 \%$ levels. The other two bands $50-70^{\circ} \mathrm{N}$ both have positive trends in EN3 and TAMARA, but the magnitude of the trend is larger in the 25 former data set.
OSD

10, 2363-2398, 2013

Comparison of $\mathbf{N}$. Atlantic heat storage

N. C. Wells et al.

\section{Title Page}

Abstract Introduction

Conclusions

References

Tables

Figures

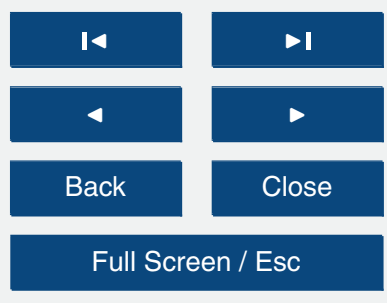

Printer-friendly Version

Interactive Discussion 


\section{Discussion and conclusion}

To further investigate the very strong trend in EN3 HCA between 1000-2000 m, the question arises whether this trend was evenly distributed across the North Atlantic, or confined to particular zonal bands. It is shown that the trends in the northernmost 5 three zonal bands $\left(40-70^{\circ} \mathrm{N}\right)$ are very much larger in EN3 than those in the TAMARA dataset. Furthermore, all the zonal trends for the 1000-2000 m layer calculated from EN3 have a much larger magnitude than the equivalent TAMARA-derived trends. The discrepancy between the EN3 and TAMARA in the deepest layer 1000-2000 $\mathrm{m}$ is very large and warrants further investigation. The results suggest that the major discrepancy arises in the higher latitudes from $40-70^{\circ} \mathrm{N}$.

A consistent difference between TAMARA and EN3 is the much larger variability in the latter data set. It is suspected that this variability is associated with the use of additional data to Argo, but also the different processing of the data and possibly different quality control procedures. The TAMARA data set may be less variable because of the more stringent quality control procedures used and there is some evidence for this from some recent reanalysis of the Argo data (King et al., 2013).

It is been found that despite the above differences between the two data sets the correspondence in both the basin trends and latitudinal bands is good between 0-1000 m. It can be concluded that the different analysis methods, quality control procedures and climatology used for the estimates of heat content anomaly, do not make a major difference to these basin wide estimates between $0-1000 \mathrm{~m}$ and on time scales greater than $1 \mathrm{yr}$.

\section{References}

Bretherton, F. P., Davis, R. E., and Fandry, C. B.: A technique for objective analysis and design of oceanographic experiments applied to MODE-73, Deep-Sea Res., 23, 559-582, 1976.

Bryden, H. L., King, B. A., and McDonagh, E. L.: Impact of a 30,\% reduction in Atlantic Meridional Overturning during 2009-2010, Nature, submitted, 2013.

2373
OSD

10, 2363-2398, 2013

Comparison of $\mathbf{N}$. Atlantic heat storage

N. C. Wells et al.

\section{Title Page}

Abstract Introduction

Conclusions

References

Tables

Figures

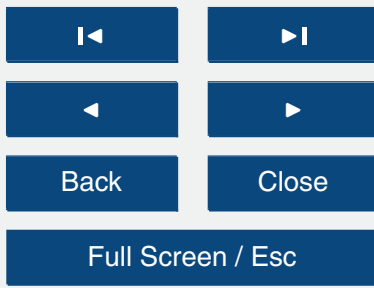

Printer-friendly Version

Interactive Discussion 
Coatanoan, C.: Coriolis Data Centre, In-situ data quality control procedures, Ifremer report, 17 pp., available at: http://www.coriolis.eu.org/content/download/4918/36060/file/ cordo-rap-04-047-quality-control.pdf, 2005.

Dickson, R., Lazier, J., Meinke, J., Rhines, P., and Swift, J.: Longterm coordinated changes in the convective activity of the North Atlantic, Prog. Oceanogr., 38, 241-295, 1996.

Dickson, R., Yashayaev, I., Meincke, J., Turrell, W., and Dye, S.: Rapid freshening of the deep North Atlantic Ocean over the past four decades, Nature, 416, 832-837, 2002.

Gandin, L. S.: Objective analysis of meteorological fields, Israel Program for Scientific Translations, 242 pp., 1965.

10 Ingleby, B. and Huddleston, M.: Quality control of ocean temperature and salinity profiles - historical and real-time data, J. Marine Syst., 65, 158-175 doi:10.1016/j.jmarsys.2005.11.019, 2007.

Ivchenko, V. O., Wells, N. C., and Aleynik, D. L.: Anomaly of heat content in the northern Atlantic in the last 7 years: is the ocean warming or cooling?, Geophys. Res. Lett., 33, L22606, doi:10.1029/2006GL027691, 2006.

Ivchenko, V. O., Wells, N. C., Aleynik, D. L., and Shaw, A. G. P.: Variability of heat and salinity content in the North Atlantic in the last decade, Ocean Sci., 6, 719-735, doi:10.5194/os-6719-2010, 2010.

King, B. A. and McDonagh, E. L.: A time series of objective mapping of Argo data in the North Atlantic, 2000-2012, J. Atmos. Ocean. Tech., in preparation, 2013.

Lavender, K. L., Owens, W. B., and Davis, R. E.: The mid-depth circulation of the subpolar North Atlantic Ocean as measured by subsurface floats, Deep-Sea Res., 52, 767-785, 2005.

Levitus, S., Boyer, T. P., and Antonov, J. I.: World Ocean Atlas 1994, 5, Interannual Variability of Upper Ocean, Thermal Structure, NOAA Atlas NESDIS 5, US Government Printing Office, Washington, D.C., 1994.

Levitus, S., Antonov, J. I., Boyer, T. P., and Stephens, C.: Warming of the world ocean, Science, 287, 2225-2229, 2000.

Levitus, S., Antonov, J. I., and Boyer, T.: Warming of the world ocean, 1955-2003, Geophys. Res. Lett., 32, L02604, doi:10.1029/2004GL021592, 2005.

30 Levitus, S., Antonov, J. I., Boyer, T. P., Locarnini, R. A., Garcia, H. E., and Mishonov, A. V.: Global ocean heat content 1955-2008 in light ofrecently revealed instrumentation problems, Geophys. Res. Lett., 36, L07608, doi:10.1029/2008GL037155, 2009.
OSD

10, 2363-2398, 2013

Comparison of $\mathbf{N}$. Atlantic heat storage

N. C. Wells et al.

\section{Title Page}

Abstract Introduction

Conclusions References

Tables

Figures

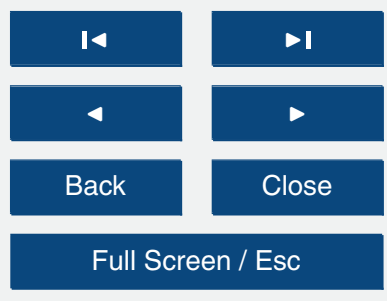

Printer-friendly Version

Interactive Discussion 
Lozier, M. S., Owens, W. B., and Curry, R. G.: The climatology of the North Atlantic, Prog. Oceanogr., 36, 1-44, 1995.

Lozier, M. S., Leadbetter, S., Williams, R. G., Roussenov, V., Reed, M. S. C., and Moore, N. J.: The spatial pattern and mechanisms of heat-content change in the North Atlantic, Science, 319, 800-803, 2008.

McCarthy, G. D., Frajka-Williams, E., Johns, W. E., Baringer, M. O., Meinen, C. S., Bryden, H. L., Rayner, D., Duchez, A., Roberts, C. D., and Cunningham, S. A.: Observed interannual variability of the Atlantic Meridional Overturning Circulation at $26.5^{\circ} \mathrm{N}$, Geophys. Res. Lett., 39, L19609, doi:10.1029/2012GL052933, 2012.

10 Stephens, C., Antonov, J. I., Boyer, T. P., Conkright, M. E., Locarnini, R., and O'Brien, T. D.: World Ocean Atlas 2001, 1: Temperature (CD-ROM), edited by: Levitus, S., NOAA Atlas NESDIS 49, US Govt. Printing Office, Washington, D.C., 2002.

Taws, S. L., Marsh, R., Wells, N. C., and Hirschi, J. J.: Re-emerging ocean temperature anomalies in late-2010 associated with a repeat negative NAO, Geophys. Res. Lett., 38, L20601, doi:10.1029/2011GL0489, 2011.

Willis, J. K., Roemmich, D., and Cornuelle, B.: Interannual variability in upper ocean heat content, temperature, and thermosteric expansion on global scales, J. Geophys. Res., 109, C12036, 2004.

Willis, J. K., Lyman, J. M., Johnson, G. C., and Gilson, J.: In situ data biases and recent ocean heat content variability, J. Atmos. Ocean. Tech., 26, 846-852, 2009.

Wong, A., Keeley, R., Carval, T., and the Argo Data Management Team: Argo quality control manual, Version 2.2. P.33, Coriolis Data Centre, available at: http://www.coriolis.eu.org/cdc/ argo/argo-quality-control-manual.pdf, 2006.

OSD

10, 2363-2398, 2013

Comparison of $\mathrm{N}$. Atlantic heat storage

N. C. Wells et al.

\section{Title Page}

Abstract

Introduction

Conclusions

References

Tables

Figures

14

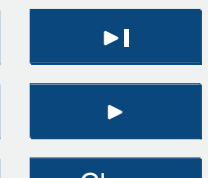

Back

Close

Full Screen / Esc

Printer-friendly Version

Interactive Discussion 
OSD

$10,2363-2398,2013$

Comparison of $\mathbf{N}$. Atlantic heat storage

N. C. Wells et al.

Table 1. 1999-2010 Trends in Heat Content Anomalies $10-70^{\circ} \mathrm{N}$.

\begin{tabular}{lccccc}
\hline $\begin{array}{l}\text { Depth range } \\
(\mathrm{m})\end{array}$ & $\begin{array}{c}\text { TAMARA } \\
\left(\times 10^{20} \mathrm{Jyr}^{-1}\right)\end{array}$ & & \multicolumn{2}{c}{$\begin{array}{c}\text { EN3, WOA01 } \\
\left(\times 10^{20} \mathrm{Jyr}^{-1}\right)\end{array}$} \\
\cline { 2 - 3 } \cline { 6 - 7 } & Trend & $\pm(95 \%)$ & & Trend & $\pm(95 \%)$ \\
\hline $0-100$ & 0.78 & 1.19 & & 0.75 & 0.99 \\
$100-500$ & 1.69 & 1.16 & & 0.89 & 2.25 \\
$500-1000$ & 1.77 & 0.95 & & 1.95 & 2.27 \\
$1000-2000$ & 1.33 & 0.73 & & 8.01 & 1.37 \\
$0-1000$ & 4.23 & 2.46 & & 3.59 & 4.73 \\
$0-2000$ & 5.56 & 2.52 & & 11.60 & 5.25 \\
\hline
\end{tabular}

Title Page

Abstract

Introduction

Conclusions

References

Tables

Figures

14

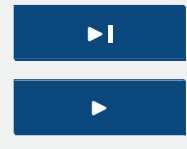

Back

Close

Full Screen / Esc

Printer-friendly Version

Interactive Discussion 
OSD

$10,2363-2398,2013$

Comparison of $\mathbf{N}$. Atlantic heat storage

N. C. Wells et al.

Table 2. Zonal North Atlantic HCA trends 1999-2010, 0-1000 m.

\begin{tabular}{lccccc}
\hline $\begin{array}{l}\text { Lat range } \\
\left({ }^{\circ} \mathrm{N}\right)\end{array}$ & $\begin{array}{c}\text { TAMARA } \\
\left(\times 10^{20} \mathrm{Jyr}^{-1}\right)\end{array}$ & & \multicolumn{2}{c}{$\begin{array}{c}\text { EN3, WOA01 } \\
\left(\times 10^{20} \mathrm{Jyr}^{-1}\right)\end{array}$} \\
\cline { 2 - 3 } \cline { 6 - 6 } & $\begin{array}{c}\text { Trend } \\
\pm(95 \%)\end{array}$ & & Trend & $\pm(95 \%)$ \\
\hline $10-20$ & -0.04 & 0.90 & & 1.33 & 1.46 \\
$20-30$ & 1.09 & 0.74 & & -1.74 & 1.36 \\
$30-40$ & -0.19 & 1.07 & & -1.93 & 1.87 \\
$40-50$ & 0.95 & 0.85 & & 1.51 & 2.20 \\
$50-60$ & 1.27 & 0.50 & & 2.71 & 0.99 \\
$60-70$ & 1.15 & 0.34 & & 1.71 & 0.78 \\
\hline
\end{tabular}

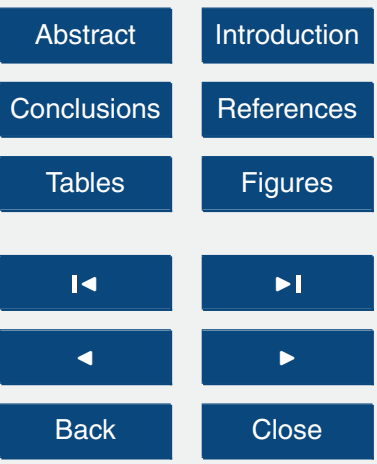

Full Screen / Esc

Printer-friendly Version

Interactive Discussion 
OSD

$10,2363-2398,2013$

Comparison of $\mathbf{N}$. Atlantic heat storage

N. C. Wells et al.

Table 3. Zonal North Atlantic HCA trends 1999-2010, 1000-2000 m.

\begin{tabular}{lccccc}
\hline $\begin{array}{l}\text { Lat range } \\
\left({ }^{\circ} \mathrm{N}\right)\end{array}$ & $\begin{array}{c}\text { TAMARA } \\
\left(\times 10^{20} \mathrm{Jyr}^{-1}\right)\end{array}$ & & \multicolumn{2}{c}{$\begin{array}{c}\text { EN3, WOA01 } \\
\left(\times 10^{20} \mathrm{Jyr}^{-1}\right)\end{array}$} \\
\cline { 2 - 3 } \cline { 6 - 6 } & Trend & $\pm(95 \%)$ & & Trend & $\pm(95 \%)$ \\
\hline $10-20$ & 0.34 & 0.11 & & 0.78 & 0.29 \\
$20-30$ & 0.25 & 0.18 & & 0.72 & 0.42 \\
$30-40$ & -0.84 & 0.47 & & -0.21 & 0.78 \\
$40-50$ & 0.46 & 0.30 & & 3.03 & 0.41 \\
$50-60$ & 0.65 & 0.12 & & 2.02 & 0.28 \\
$60-70$ & 0.47 & 0.06 & & 1.67 & 0.21 \\
\hline
\end{tabular}

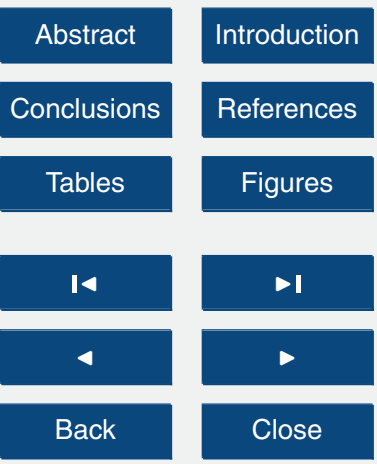

Full Screen / Esc

Printer-friendly Version

Interactive Discussion 
OSD

$10,2363-2398,2013$

Comparison of $\mathbf{N}$. Atlantic heat storage

N. C. Wells et al.

Table 4. 1999-2008 Trends in Heat Content Anomalies 10-70 N.

\begin{tabular}{lccccc}
\hline $\begin{array}{l}\text { Depth range } \\
(\mathrm{m})\end{array}$ & $\begin{array}{c}\text { TAMARA } \\
\left(\times 10^{20} \mathrm{Jyr}^{-1}\right)\end{array}$ & & \multicolumn{2}{c}{$\begin{array}{c}\text { EN3, WOA01 } \\
\left(\times 10^{20} \mathrm{Jyr}^{-1}\right)\end{array}$} \\
\cline { 2 - 3 } \cline { 6 - 7 } & Trend & $\pm(95 \%)$ & & Trend & $\pm(95 \%)$ \\
\hline $0-100$ & 1.45 & 1.59 & & 2.16 & 1.23 \\
$100-500$ & 4.12 & 1.48 & & 3.59 & 3.05 \\
$500-1000$ & 3.85 & 1.18 & & 4.21 & 3.09 \\
$1000-2000$ & 1.02 & 0.93 & & 10.27 & 1.74 \\
$0-1000$ & 9.42 & 3.09 & & 9.96 & 6.39 \\
$0-2000$ & 10.44 & 3.16 & & 20.22 & 6.93 \\
\hline
\end{tabular}

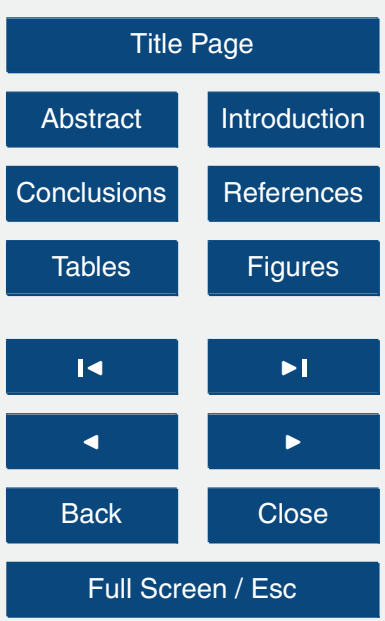

Printer-friendly Version

Interactive Discussion 
OSD

$10,2363-2398,2013$

Comparison of $\mathbf{N}$. Atlantic heat storage

N. C. Wells et al.

Table 5. Zonal North Atlantic HCA Trends 1999-2008, 0-1000 m.

\begin{tabular}{lccccc}
\hline $\begin{array}{l}\text { Lat range } \\
\left({ }^{\circ} \mathrm{N}\right)\end{array}$ & $\begin{array}{c}\text { TAMARA } \\
\left(\times 10^{20} \mathrm{Jyr}^{-1}\right)\end{array}$ & & \multicolumn{2}{c}{$\begin{array}{c}\text { EN3, WOA01 } \\
\left(\times 10^{20} \mathrm{Jyr}^{-1}\right)\end{array}$} \\
\cline { 2 - 3 } \cline { 5 - 6 } & Trend & $\pm(95 \%)$ & & Trend & $\pm(95 \%)$ \\
\hline $10-20$ & 0.95 & 1.08 & & 3.24 & 1.83 \\
$20-30$ & 1.63 & 0.98 & & -0.81 & 1.86 \\
$30-40$ & 1.59 & 1.31 & & 0.22 & 2.40 \\
$40-50$ & 1.36 & 1.16 & & -0.25 & 2.89 \\
$50-60$ & 2.29 & 0.64 & & 4.76 & 1.23 \\
$60-70$ & 1.59 & 0.44 & & 2.80 & 0.93 \\
\hline
\end{tabular}

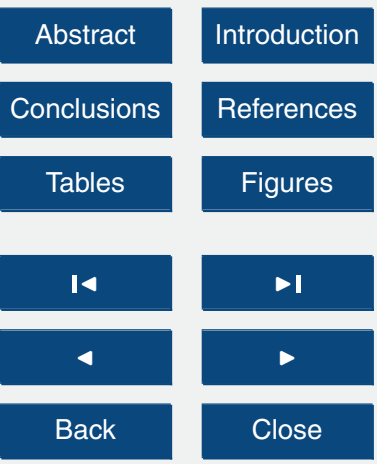

Full Screen / Esc

Printer-friendly Version

Interactive Discussion 
OSD

$10,2363-2398,2013$

Comparison of $\mathbf{N}$. Atlantic heat storage

N. C. Wells et al.

Table 6. 1999-2010 Correlation between EN3 and TAMARA Heat Content Anomalies 10$70^{\circ} \mathrm{N}$.

\begin{tabular}{lcc}
\hline Depth Range $(\mathrm{m})$ & Corr Coef & $P$ value \\
\hline $0-100$ & 0.43 & $1.07 \times 10^{-7}$ \\
$100-500$ & 0.52 & $2.46 \times 10^{-11}$ \\
$500-1000$ & 0.52 & $1.58 \times 10^{-11}$ \\
$1000-2000$ & 0.47 & $3.43 \times 10^{-9}$ \\
$0-1000$ & 0.44 & $3.41 \times 10^{-8}$ \\
$0-2000$ & 0.51 & $9.94 \times 10^{-11}$ \\
\hline
\end{tabular}

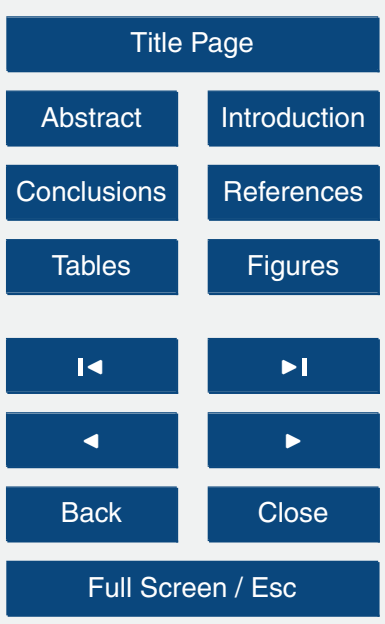

Printer-friendly Version

Interactive Discussion 
OSD

$10,2363-2398,2013$

Comparison of $\mathrm{N}$. Atlantic heat storage

N. C. Wells et al.

Table 7. 1999-2010 Standard deviation in de-trended heat content anomalies $10-70^{\circ} \mathrm{N}$.

\begin{tabular}{lcc}
\hline $\begin{array}{l}\text { Depth Range } \\
(\mathrm{m})\end{array}$ & \begin{tabular}{c} 
TAMARA $^{\left(\mathrm{Jyr}^{-1}\right)}$ \\
\hline $0-100$
\end{tabular} & $\begin{array}{c}\text { EN3, WOA01 } \\
\left(\mathrm{Jyr}^{-1}\right)\end{array}$ \\
$100-500$ & $2.50 \times 10^{21}$ & $2.08 \times 10^{21}$ \\
$500-1000$ & $2.00 \times 10^{21}$ & $4.71 \times 10^{21}$ \\
$1000-2000$ & $1.52 \times 10^{21}$ & $4.77 \times 10^{21}$ \\
$0-1000$ & $5.15 \times 10^{21}$ & $9.91 \times 10^{21}$ \\
$0-2000$ & $5.27 \times 10^{21}$ & $1.10 \times 10^{22}$ \\
\hline
\end{tabular}

Title Page

Abstract

Introduction

Conclusions

References

Tables

Figures

14

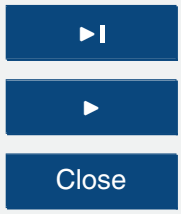

Back

Close

Full Screen / Esc

Printer-friendly Version

Interactive Discussion 
OSD

$10,2363-2398,2013$

Comparison of $\mathbf{N}$. Atlantic heat storage

N. C. Wells et al.

Title Page

Table 8. Correlation $(r)$ and standard deviation of detrended TAMARA and EN3.

\begin{tabular}{lcccc}
\hline & 1 month & 3 month & 6 month & 12 month \\
\hline$r$ & 0.44 & 0.68 & 0.74 & 0.89 \\
TAMARA Std $\times 10^{21} \mathrm{~J}$ & 5.2706 & 4.4430 & 3.9359 & 3.2341 \\
EN3 Std $\times 10^{21} \mathrm{~J}$ & 10.998 & 7.1253 & 6.3708 & 5.7046 \\
\hline
\end{tabular}

Abstract

Introduction

Conclusions

References

Tables

Figures

14

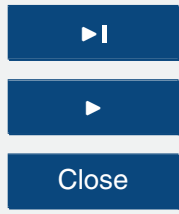

Full Screen / Esc

Printer-friendly Version

Interactive Discussion 
OSD

$10,2363-2398,2013$

Comparison of $\mathbf{N}$. Atlantic heat storage

N. C. Wells et al.

Table 9. 2008-2010 Trends in Heat Content Anomalies 10-70 N.

\begin{tabular}{|c|c|c|c|c|}
\hline \multirow[t]{2}{*}{$\begin{array}{l}\text { Depth range } \\
\text { (m) }\end{array}$} & \multicolumn{2}{|c|}{$\begin{array}{c}\text { TAMARA } \\
\left(\times 10^{20} \mathrm{Jyr}^{-1}\right)\end{array}$} & \multicolumn{2}{|c|}{$\begin{array}{l}\text { EN3, WOA01 } \\
\left(\times 10^{20} \mathrm{Jyr}^{-1}\right)\end{array}$} \\
\hline & Trend & \pm & Trend & \pm \\
\hline $0-100$ & -3.58 & 9.25 & 1.94 & 8.74 \\
\hline $100-500$ & -10.7 & 5.12 & -10.10 & 12.1 \\
\hline $500-1000$ & -9.16 & 6.64 & -5.59 & 15.4 \\
\hline $1000-2000$ & 1.44 & 6.51 & 6.68 & 8.95 \\
\hline $0-1000$ & -23.4 & 13.7 & -13.8 & 26.6 \\
\hline $0-2000$ & -22.0 & 14.7 & -7.10 & 30.0 \\
\hline
\end{tabular}

Title Page

\section{Abstract}

Introduction

Conclusions

References

Tables

Figures

14

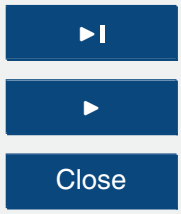

Back

Close

Full Screen / Esc

Printer-friendly Version

Interactive Discussion 
OSD

$10,2363-2398,2013$

Comparison of $\mathbf{N}$. Atlantic heat storage

N. C. Wells et al.

Table 10. Zonal North Atlantic HCA trends 2008-2010, 0-2000 m, $95 \%$ significance.

\begin{tabular}{|c|c|c|c|c|}
\hline \multirow[t]{2}{*}{$\begin{array}{l}\text { Lat range } \\
\left({ }^{\circ} \mathrm{N}\right)\end{array}$} & \multicolumn{2}{|c|}{$\begin{array}{c}\text { TAMARA } \\
\left(\times 10^{20} \mathrm{Jyr}^{-1}\right)\end{array}$} & \multicolumn{2}{|c|}{$\begin{array}{l}\text { EN3, WOA01 } \\
\left(\times 10^{20} \mathrm{Jyr}^{-1}\right)\end{array}$} \\
\hline & Trend & \pm & Trend & \pm \\
\hline $10-20$ & 9.16 & 8.07 & 9.45 & 10.63 \\
\hline $20-30$ & -6.16 & 5.07 & 2.71 & 8.29 \\
\hline $30-40$ & -28.82 & 8.98 & -39.28 & 14.36 \\
\hline $40-50$ & -6.07 & 5.89 & -1.48 & 17.17 \\
\hline $50-60$ & 5.98 & 2.27 & 10.12 & 7.12 \\
\hline $60-70$ & 3.92 & 2.13 & 11.38 & 7.77 \\
\hline
\end{tabular}

Title Page

Abstract

Introduction

Conclusions

References

Tables

Figures

14

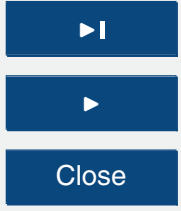

Back

Close

Full Screen / Esc

Printer-friendly Version

Interactive Discussion 

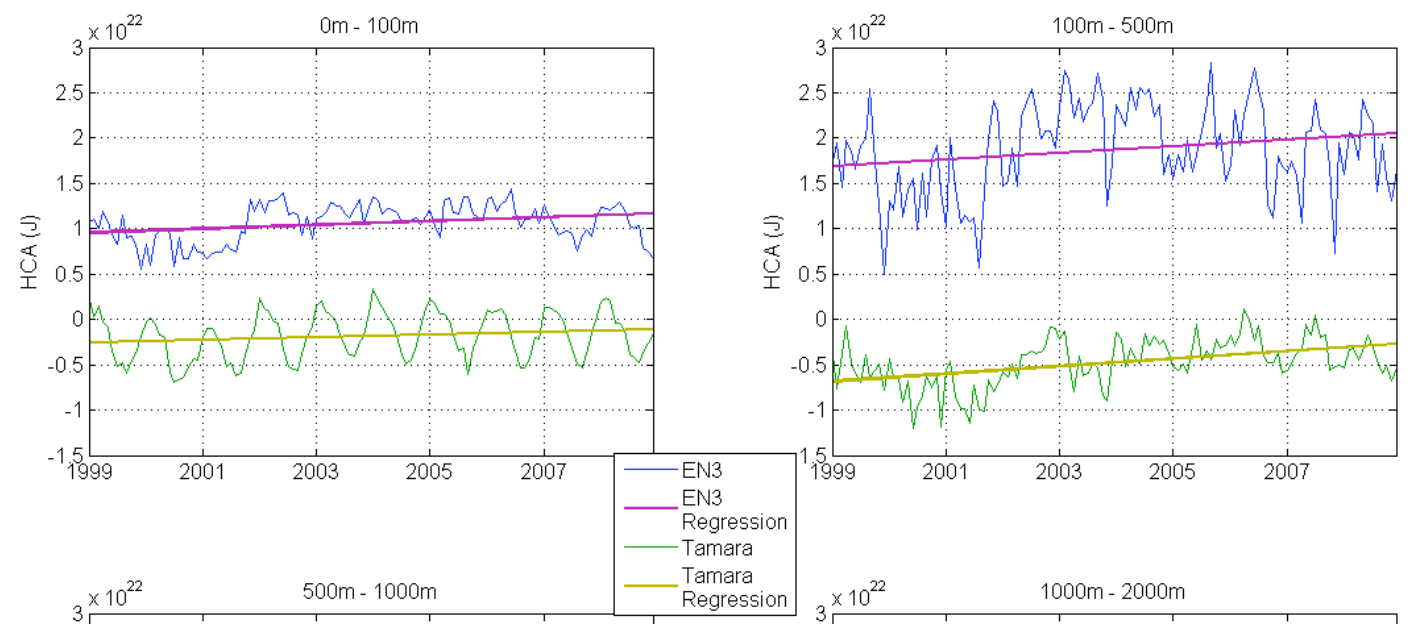

OSD

10, 2363-2398, 2013

Comparison of $\mathbf{N}$. Atlantic heat storage

N. C. Wells et al.

Title Page

Abstract

Introduction

Conclusions

References
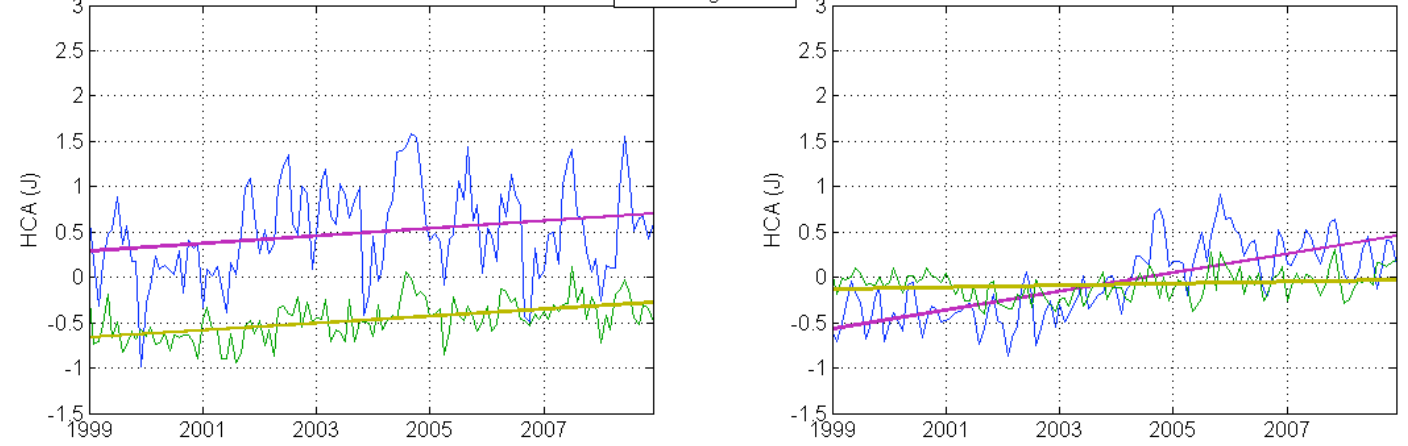

Tables

Figures

14

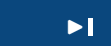

4

Back

Close

Full Screen / Esc

Printer-friendly Version

Fig. 1. Time series of two datasets of Heat Content Anomalies (HCA, J) of the North Atlantic, $10-70^{\circ} \mathrm{N}$, January $1999-$ December 2010 in four depth layers: $0-100 \mathrm{~m}, 100-500 \mathrm{~m}$,

Interactive Discussion 500-1000 $\mathrm{m}$ and $1000-2000 \mathrm{~m}$. 


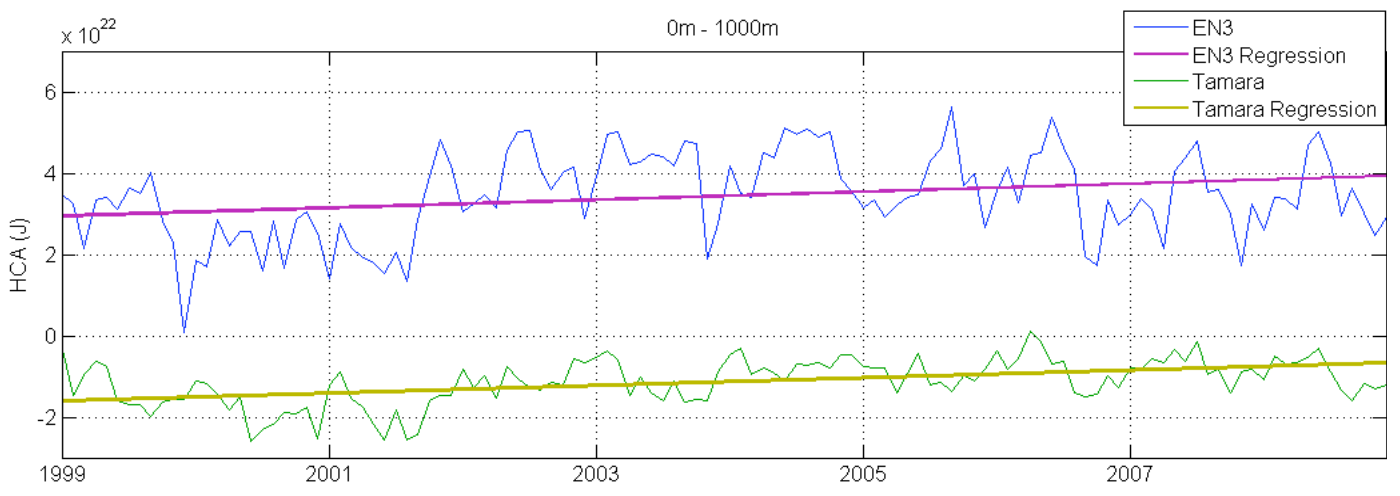

OSD

10, 2363-2398, 2013

Comparison of $\mathbf{N}$. Atlantic heat storage

N. C. Wells et al.

Title Page

Abstract

Introduction

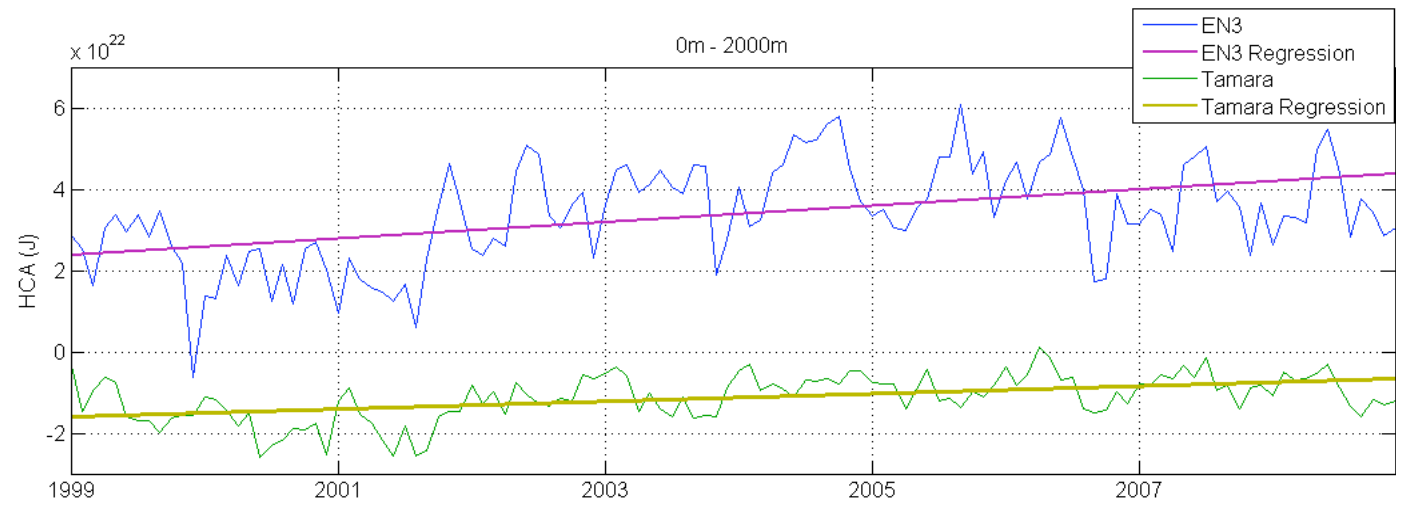

Conclusions

References

Tables

Figures

14

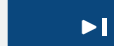

4

Back

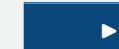

Close

Full Screen / Esc

Printer-friendly Version

Fig. 2. HCA of the North Atlantic for uppermost 1000 and $2000 \mathrm{~m}$, January 1999-December 2010.

Interactive Discussion

(c) (I) 


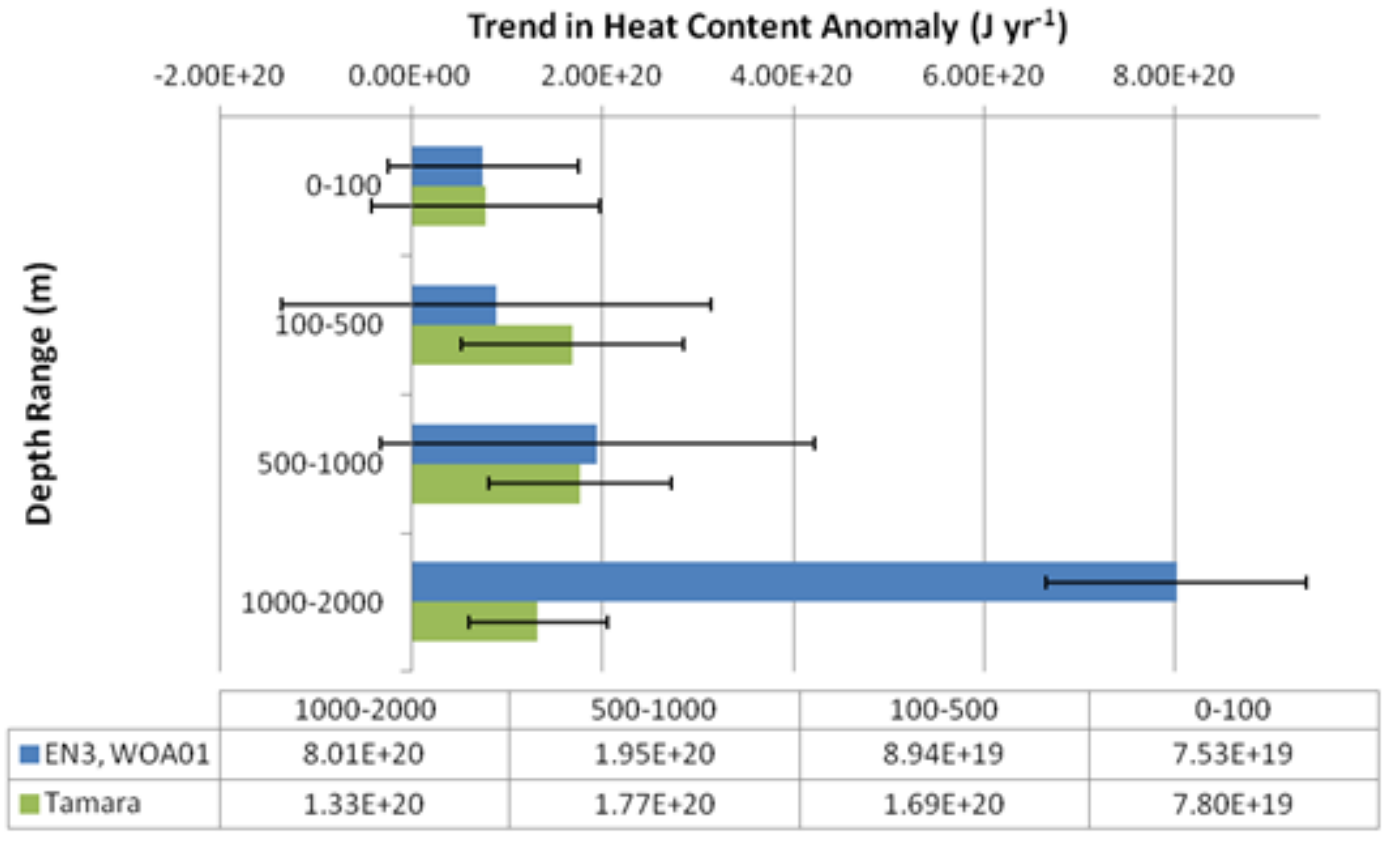

Fig. 3. $1999-2010$ Trends in Heat Content Anomalies $10-70^{\circ} \mathrm{N}$ in four depth levels.
OSD

10, 2363-2398, 2013

Comparison of $\mathbf{N}$. Atlantic heat storage

N. C. Wells et al.

Title Page

Abstract

Introduction

Conclusions

References

Tables

Figures

14

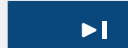

4

Back

Close

Full Screen / Esc

Printer-friendly Version

Interactive Discussion 


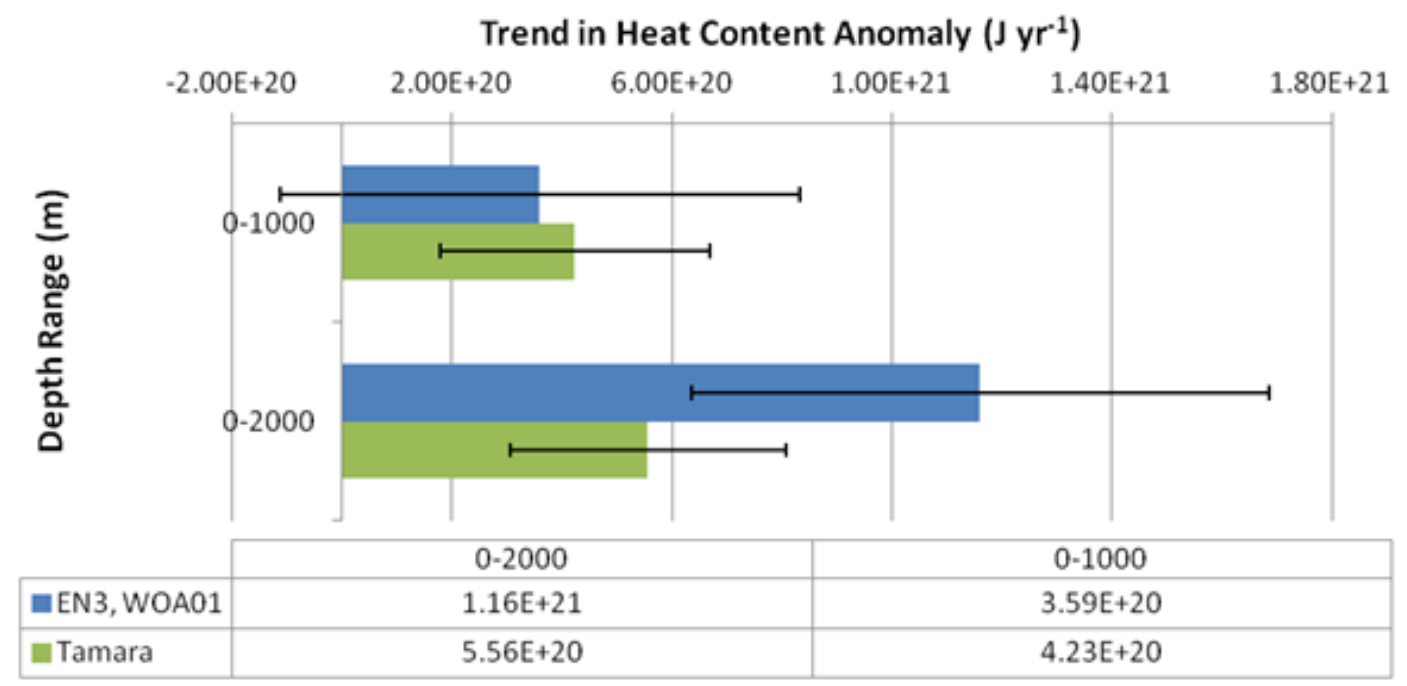

Fig. 4. 1999-2010 Trends in Heat Content Anomalies $10-70^{\circ} \mathrm{N}$ in two depth levels.
OSD

10, 2363-2398, 2013

Comparison of $\mathbf{N}$. Atlantic heat storage

N. C. Wells et al.

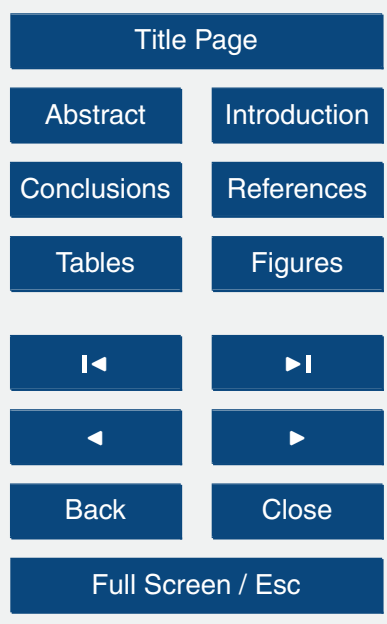

Printer-friendly Version

Interactive Discussion 


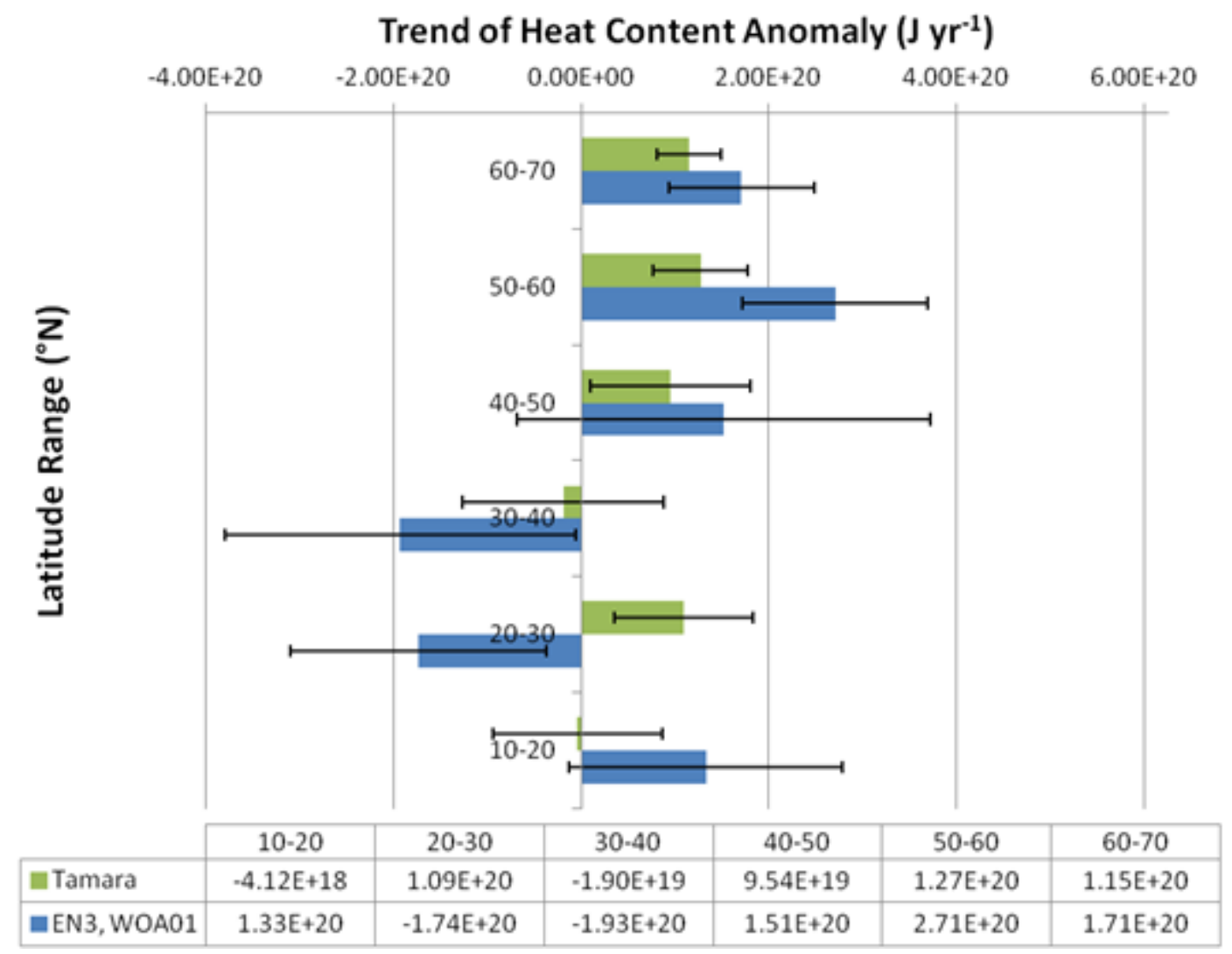

OSD

10, 2363-2398, 2013

Comparison of $\mathbf{N}$. Atlantic heat storage

N. C. Wells et al.

\begin{tabular}{|c|c|}
\hline \multicolumn{2}{|c|}{ Title Page } \\
\hline Abstract & Introduction \\
\hline Conclusions & References \\
\hline Tables & Figures \\
\hline & \\
\hline I4 & $\bullet \mathbf{I}$ \\
\hline 4 & $\bullet$ \\
\hline Back & Close \\
\hline Full Screen / Esc \\
\hline
\end{tabular}

Fig. 5. Zonal North Atlantic HCA trends 1999-2010, 0-1000 m.

Printer-friendly Version

Interactive Discussion

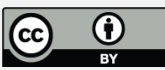




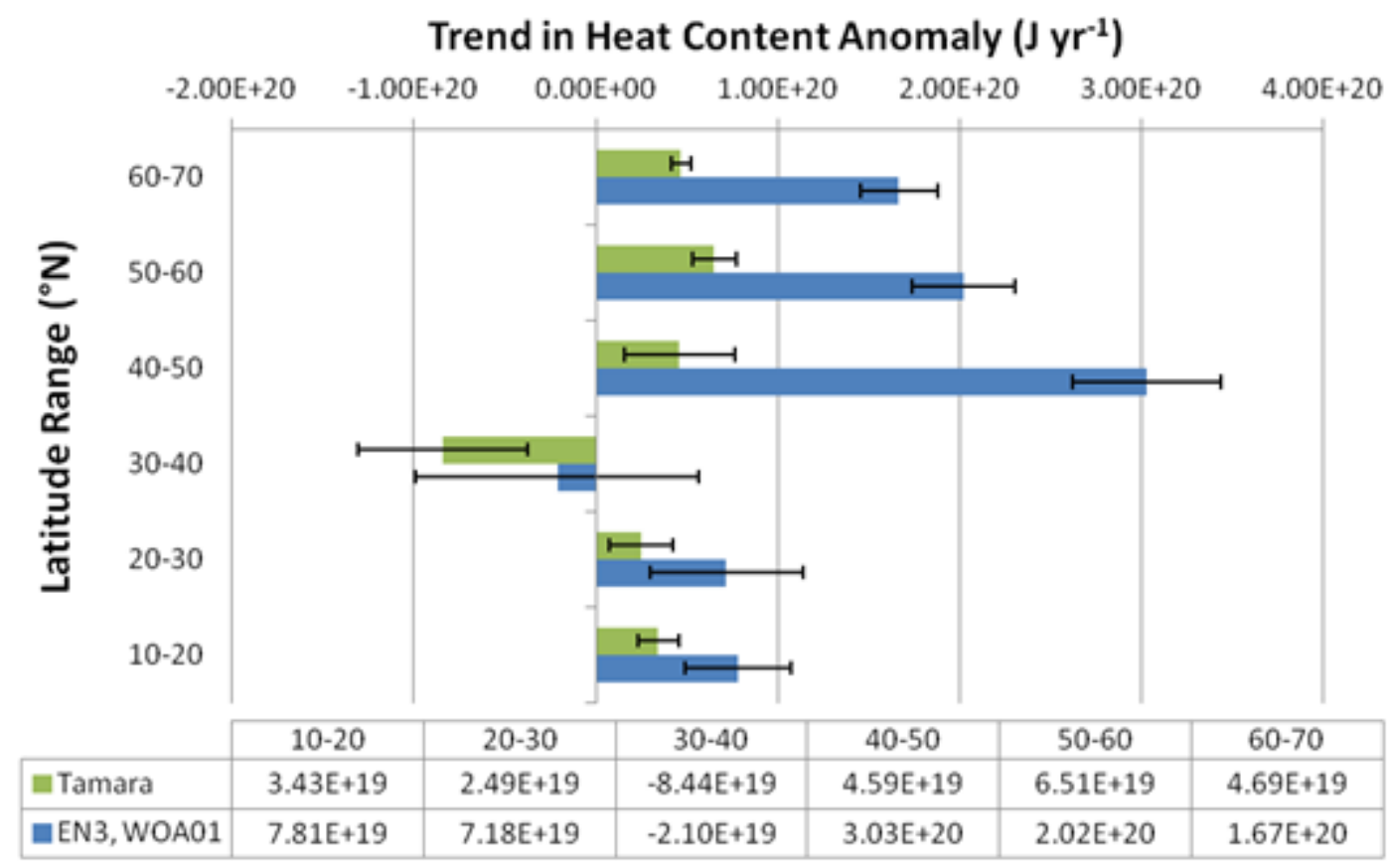

OSD

10, 2363-2398, 2013

Comparison of $\mathbf{N}$. Atlantic heat storage

N. C. Wells et al.

\begin{tabular}{|c|c|}
\hline \multicolumn{2}{|c|}{ Title Page } \\
\hline Abstract & Introduction \\
\hline Conclusions & References \\
\hline Tables & Figures \\
\hline & \\
\hline I4 & $\bullet \mathbf{I}$ \\
\hline 4 & $\bullet$ \\
\hline Back & Close \\
\hline Full Screen / Esc \\
\hline
\end{tabular}

Fig. 6. Zonal North Atlantic HCA trends 1999-2010, 1000-2000 m.

Printer-friendly Version

Interactive Discussion

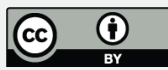




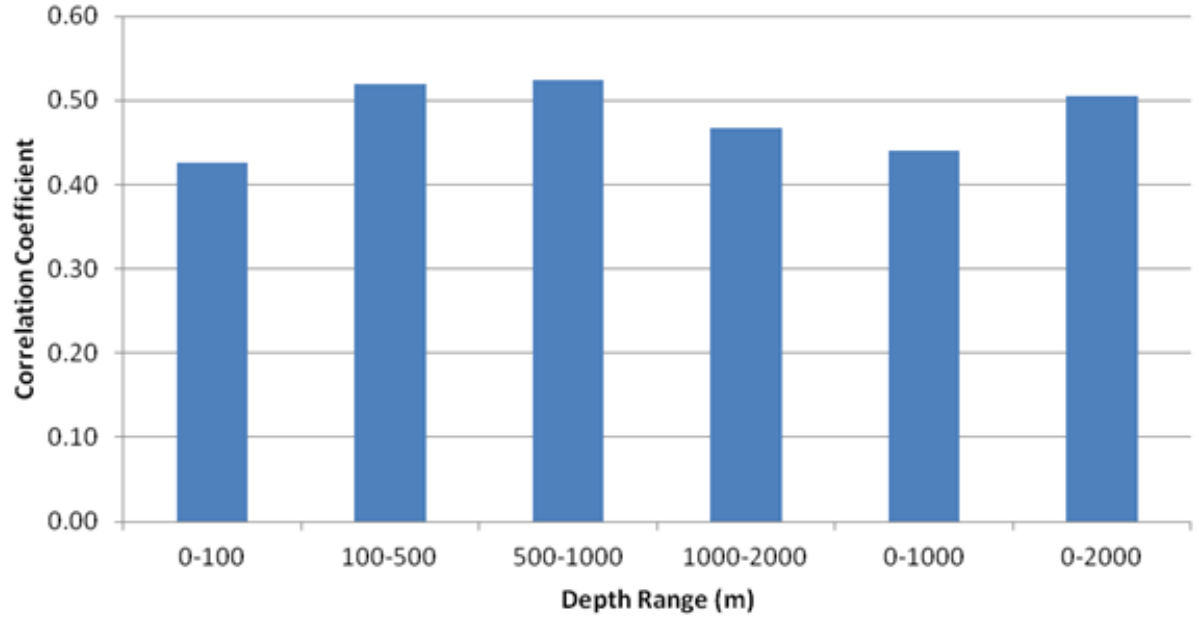

Fig. 7. Correlations between EN3 and TAMARA Heat Content Anomalies $10-70^{\circ} \mathrm{N}$.
OSD

10, 2363-2398, 2013

Comparison of $\mathbf{N}$. Atlantic heat storage

N. C. Wells et al.

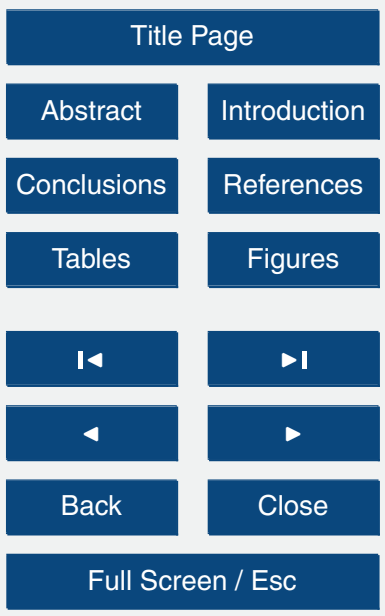

Printer-friendly Version

Interactive Discussion 


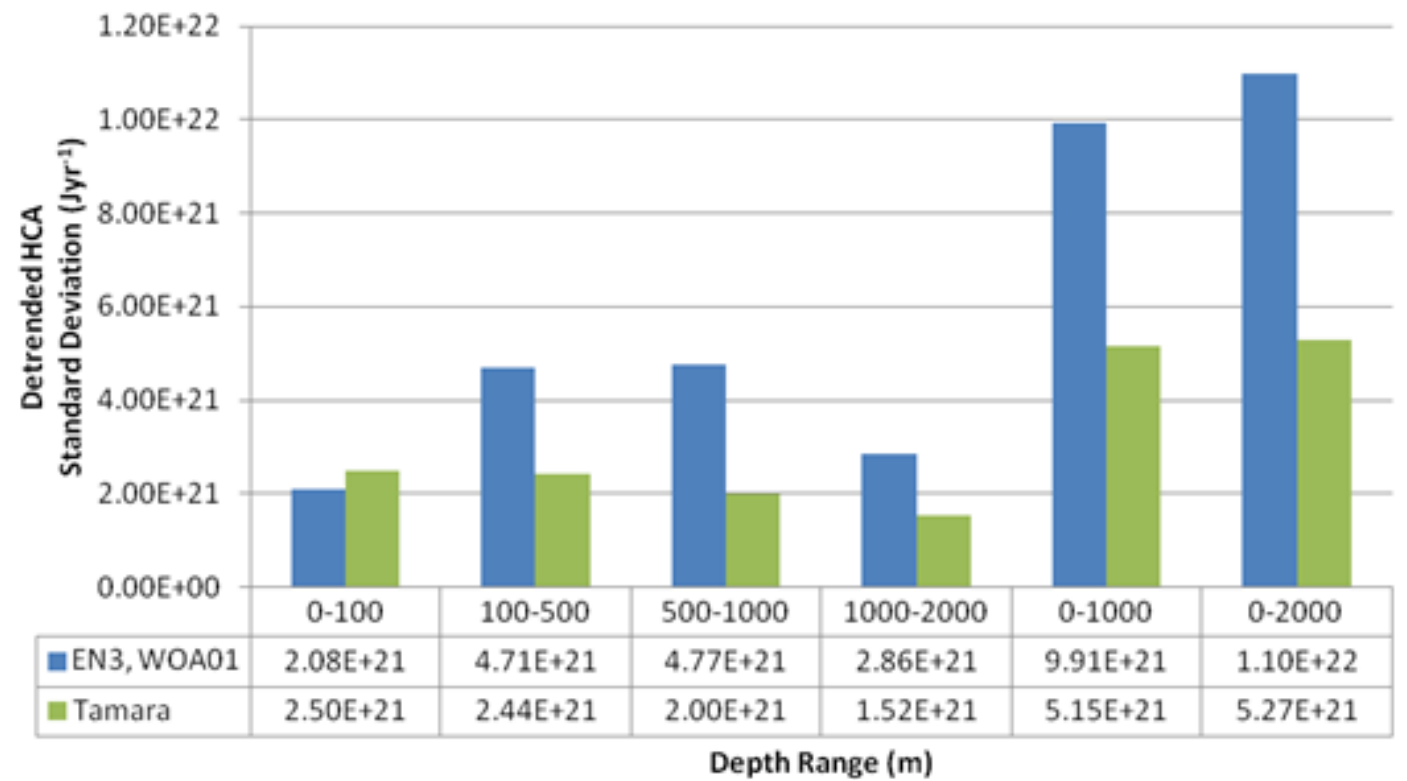

Fig. 8. 1999-2010 Standard deviations of de-trended HCA time series.
OSD

10, 2363-2398, 2013

Comparison of $\mathbf{N}$. Atlantic heat storage

N. C. Wells et al.

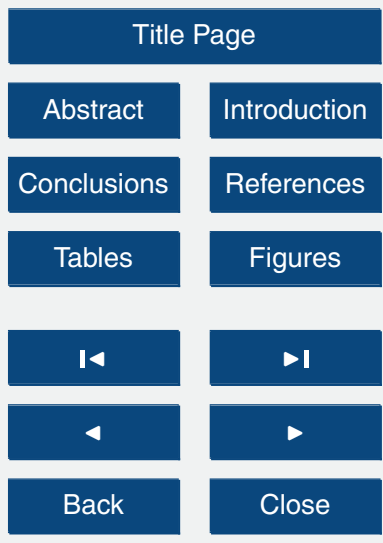

Full Screen / Esc

Printer-friendly Version

Interactive Discussion 

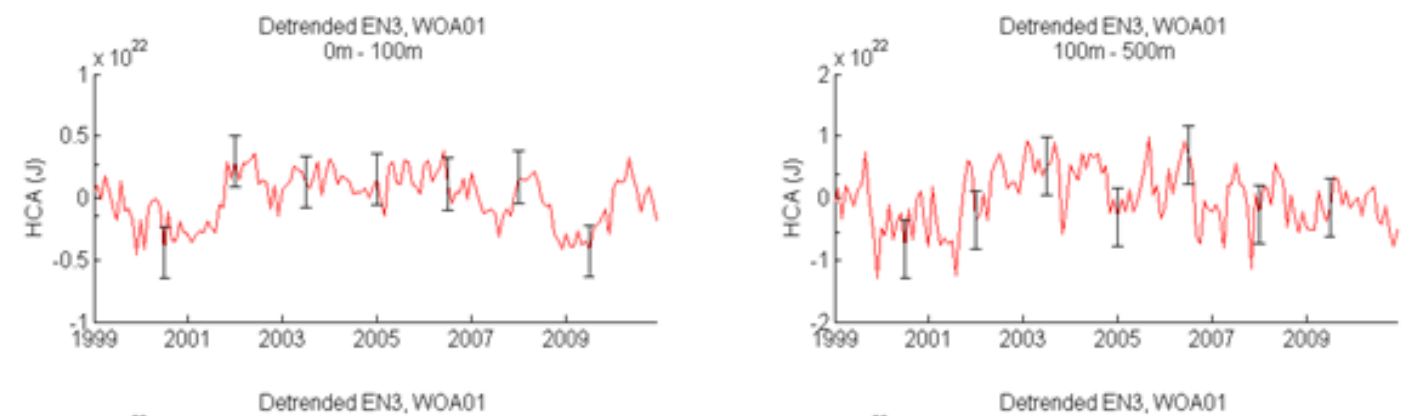

OSD

10, 2363-2398, 2013
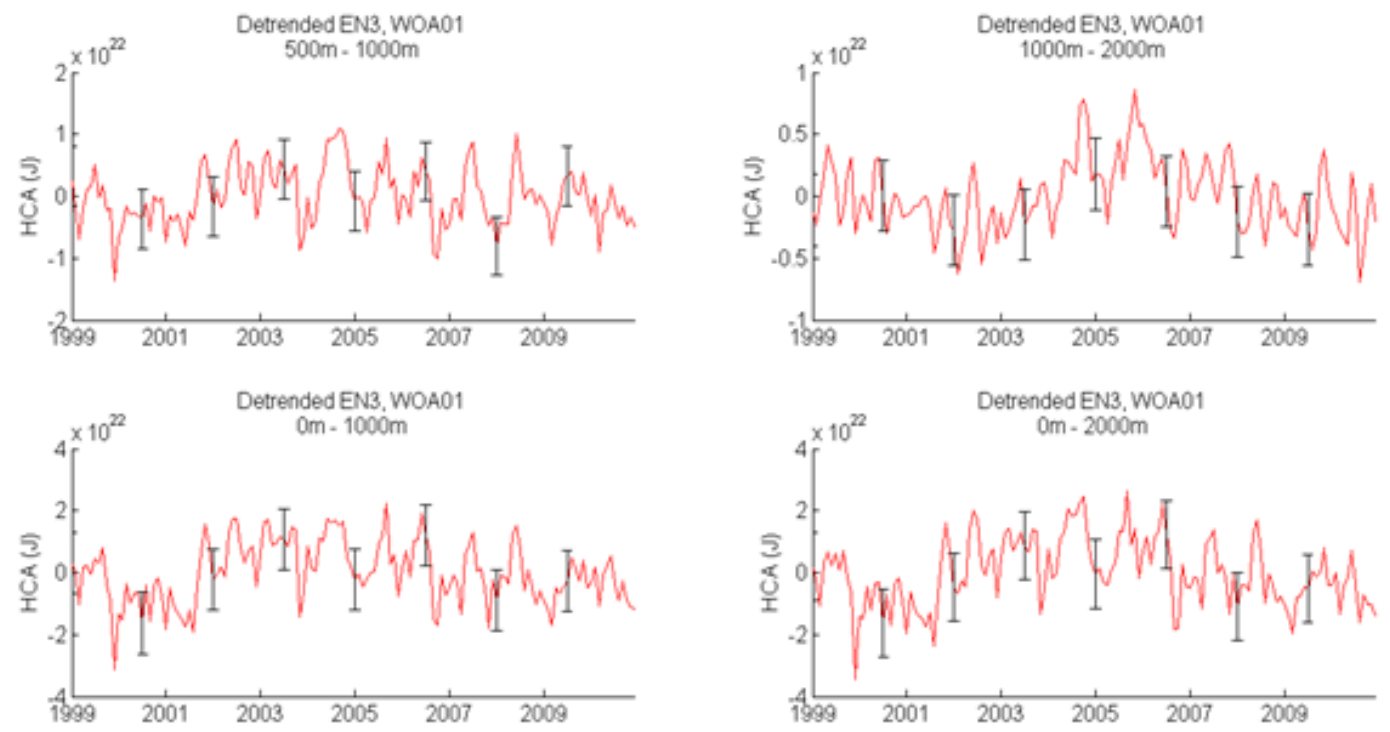

Comparison of $\mathbf{N}$. Atlantic heat storage

N. C. Wells et al.

Title Page

Abstract

Introduction

Conclusions

References

Tables

Figures

14

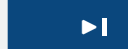

4

Back

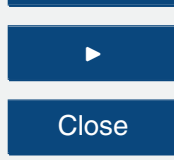

Full Screen / Esc

Printer-friendly Version

Interactive Discussion

(6) (1) 

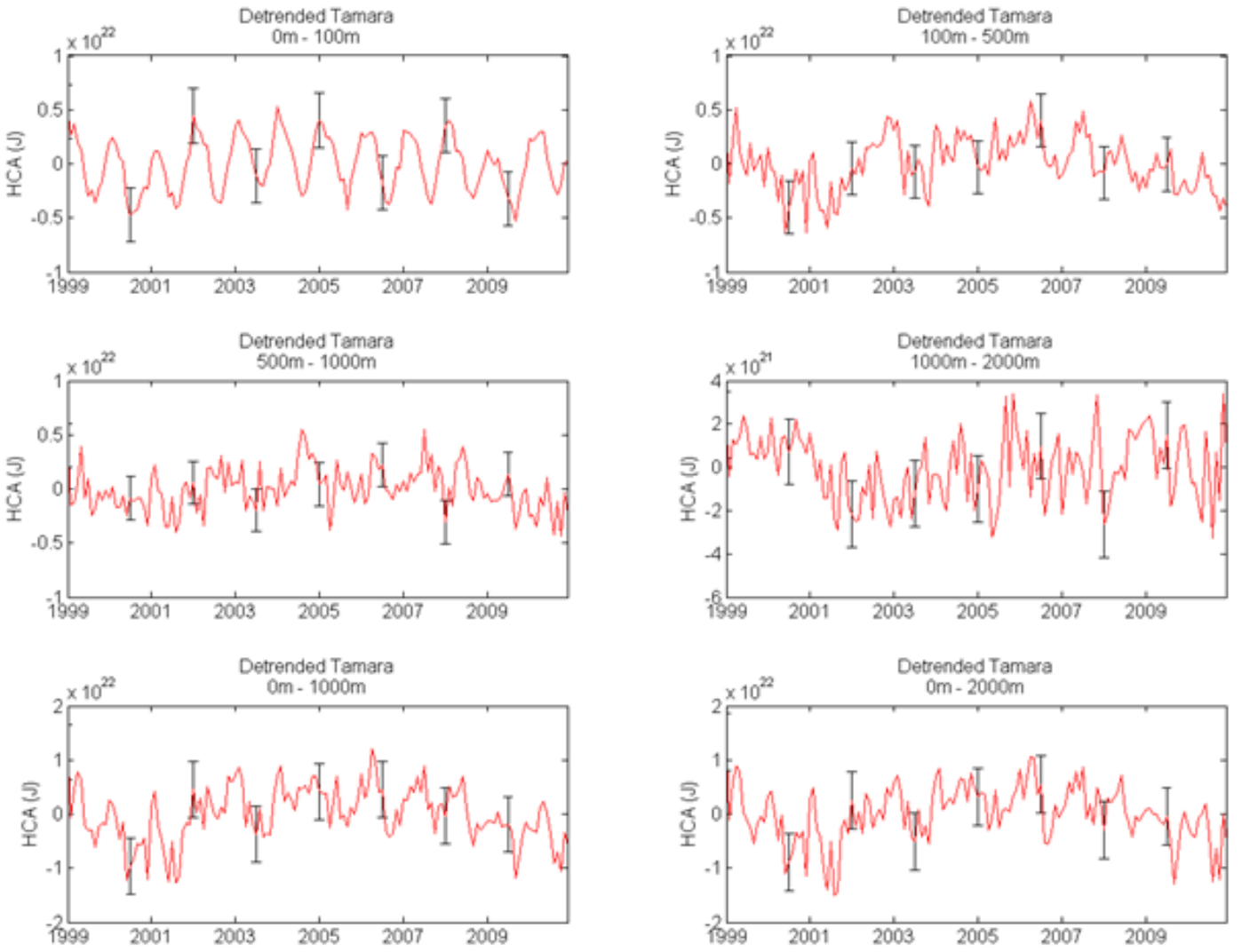

Fig. 10. Time series of TAMARA layer HCA with linear trend removed and error bars showing \pm 1 standard deviation.
OSD

10, 2363-2398, 2013

Comparison of $\mathbf{N}$. Atlantic heat storage

N. C. Wells et al.

Title Page

Abstract

Introduction

Conclusions

References

Tables

Figures

14

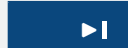

4

Back

Close

Full Screen / Esc

Printer-friendly Version

Interactive Discussion 


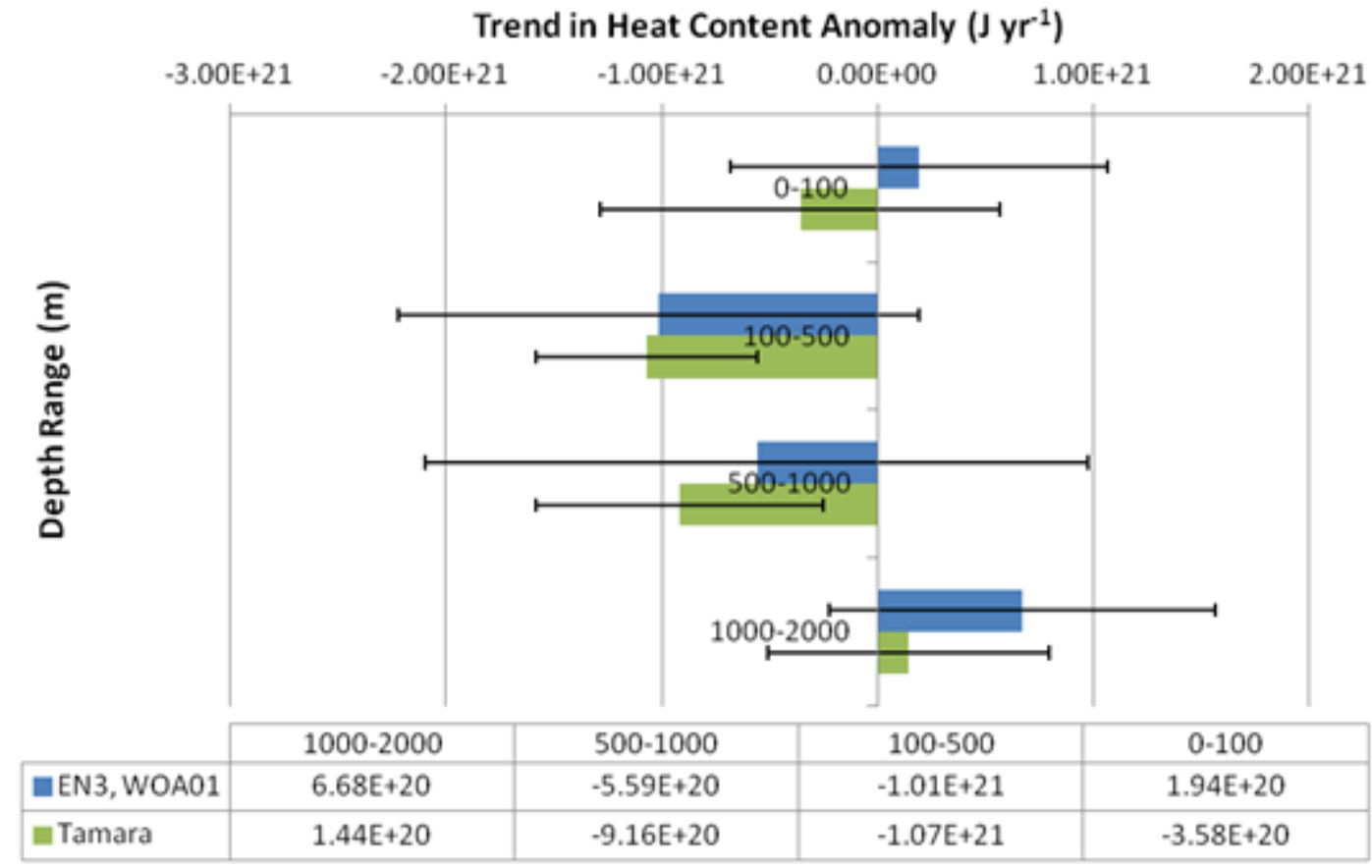

OSD

10, 2363-2398, 2013

Comparison of $\mathbf{N}$. Atlantic heat storage

N. C. Wells et al.

Title Page

Abstract

Introduction

Conclusions

References

Tables

Figures

14

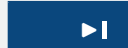

4

Back

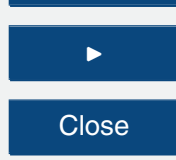

Full Screen / Esc

Printer-friendly Version

Interactive Discussion

(c) (i) 


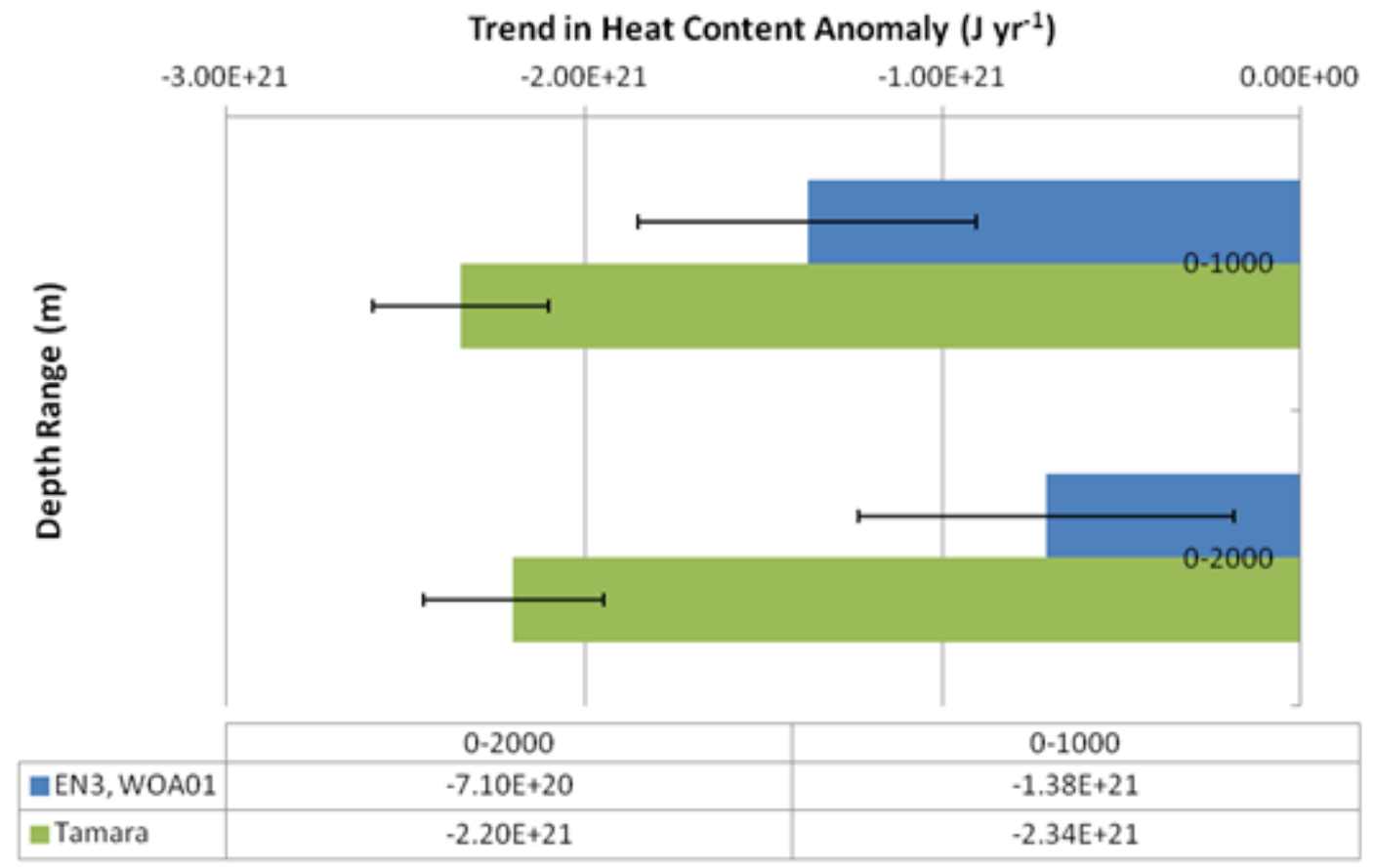

OSD

10, 2363-2398, 2013

Comparison of $\mathbf{N}$. Atlantic heat storage

N. C. Wells et al.

Title Page

Abstract

Introduction

Conclusions

References

Tables

Figures

14

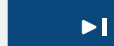

4

Back

Full Screen / Esc

Printer-friendly Version

Interactive Discussion

(c) (i) 


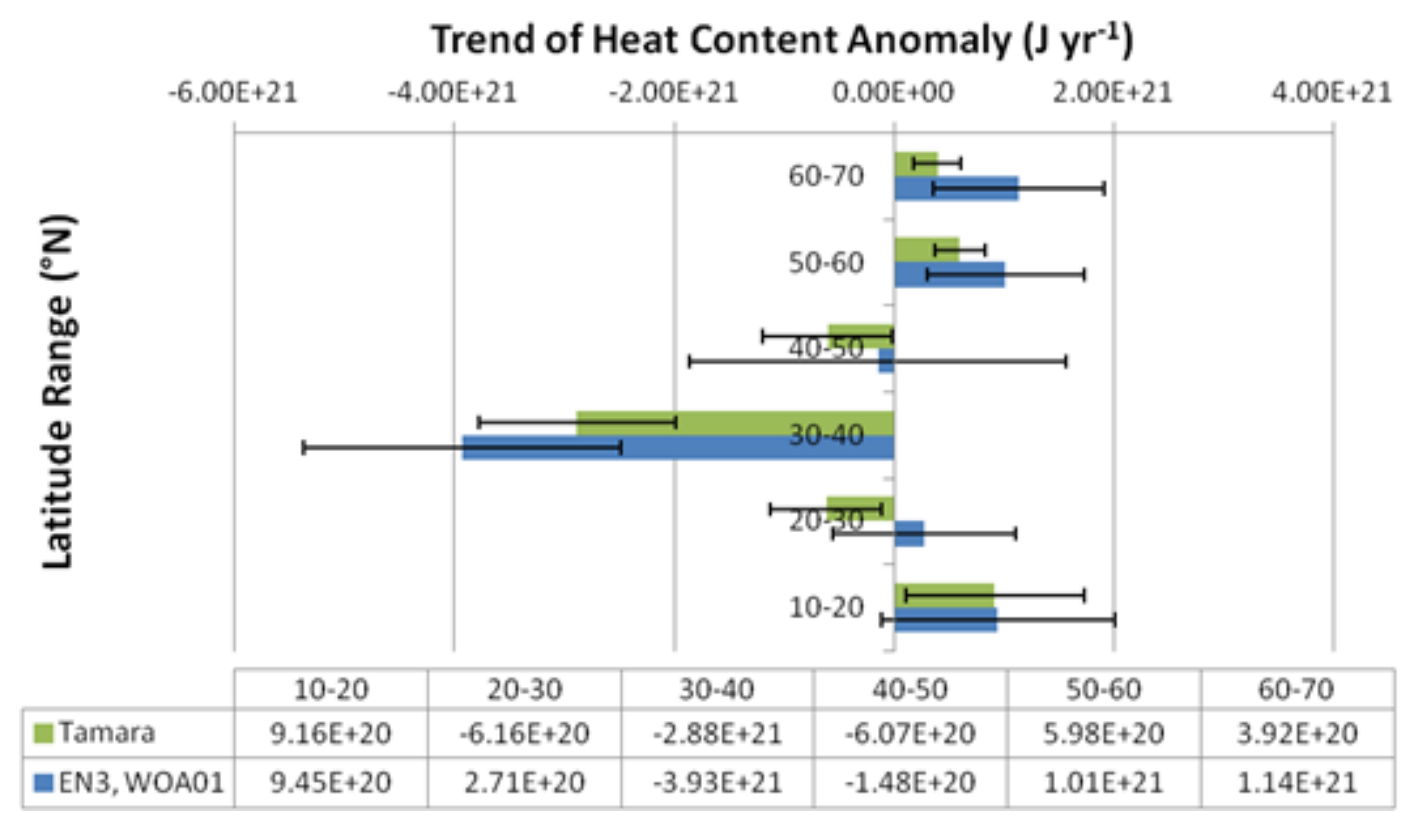

Fig. 13. Zonal North Atlantic HCA trends 2008-2010, 0-2000 m.
OSD

10, 2363-2398, 2013

Comparison of $\mathbf{N}$. Atlantic heat storage

N. C. Wells et al.

\begin{tabular}{|c|c|}
\hline \multicolumn{2}{|c|}{ Title Page } \\
\hline Abstract & Introduction \\
\hline Conclusions & References \\
\hline Tables & Figures \\
\hline & \\
\hline I & $\bullet$ \\
\hline 4 & $\triangleright$ \\
\hline Back & Close \\
\hline Full Screen / Esc \\
\hline
\end{tabular}

Printer-friendly Version

Interactive Discussion 